\title{
Resolving the Intergenerational Conflicts in Real Property Law: Preserving Free Markets and Personal Autonomy for Future Generations
}

Gerald Korngold

New York Law School

Follow this and additional works at: https://digitalcommons.nyls.edu/fac_articles_chapters

Part of the Property Law and Real Estate Commons

\section{Recommended Citation}

56 American University Law Review 1525-1578 (2007)

This Article is brought to you for free and open access by the Faculty Scholarship at DigitalCommons@NYLS. It has been accepted for inclusion in Articles \& Chapters by an authorized administrator of DigitalCommons@NYLS. 


\title{
RESOLVING THE INTERGENERATIONAL CONFLICTS OF REAL PROPERTY LAW: PRESERVING FREE MARKETS AND PERSONAL AUTONOMY FOR FUTURE GENERATIONS*
}

\author{
GERALD KORNGOLD**
}

\section{TABLE OF CONTENTS}

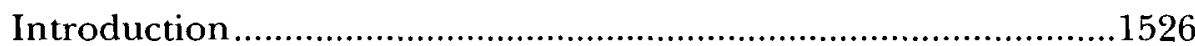

I. Land Ownership in the American Experience .....................1532

A. A Valuable Commodity ...............................................1533

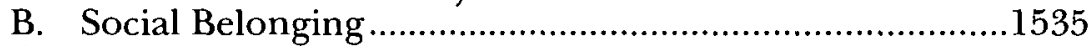

C. Land and Democracy ................................................1538

II. The Intergenerational Compact.........................................1539

III. Competing Themes in American Land Law .........................1542

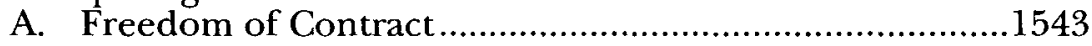

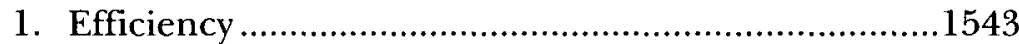

a. Market benefits...............................................1543

b. Differences with traditional contract ..................1545

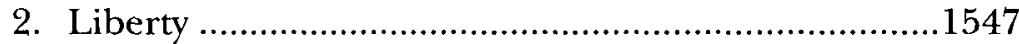

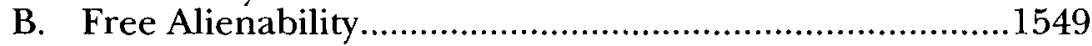

1. Promoting a market economy ..................................1550

2. Dead hand control............................................1553

IV. Accommodating Contract and Alienability for Future

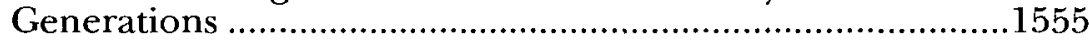

* C Gerald Korngold 2007. All rights reserved.

* Everett D. and Eugenia S. McCurdy Professor of Law, Case Western Reserve University School of Law, Visiting Fellow, Lincoln Institute of Land Policy, Cambridge, Massachusetts. I wish to express my appreciation to Dean Richard Revesz for graciously hosting me as a Visiting Scholar at New York University School of Law during 2006-2007; to the faculty workshops at New York University School of Law, New York Law School, Rutgers-Camden School of Law, Rutgers-Newark School of Law, and Temple University Beasley School of Law for their valuable feedback; and to Susan French, Katrina Wyman, and Kathy Zeiler for their helpful, detailed comments. Of course, opinions and errors are mine alone. 
A. Scenario 1: Unclear Undertakings by First Generation Parties

B. Scenario 2: System Architecture and Operation 1562

1. Improper escrow delivery ........................................1562

2. Recording rules...................................................1564

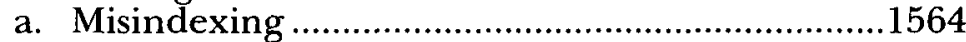

b. Inquiry notice .....................................................1565

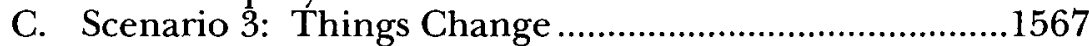

1. Relocation of easements ........................................1568

2. Changed conditions.................................................1569

D. Scenario 4: Poor Predictions by Private Parties ..............1571

1. Residential communities ...........................................1571

2. Conservation easements ........................................1575

E. Scenario 5: The End of the Eminent Domain Trump Card?

\section{INTRODUCTION}

In 1923, the urban landscape of Tokyo was devastated by the Great Kanto Earthquake. The disaster claimed tens of thousands of lives and razed entire sections of the city. Searching for answers, investigators examined how some structures withstood the quake. Many of the flattened buildings had been designed and erected without consideration for the unavoidable. Other destroyed structures had been constructed based on the prevailing theory of earthquake engineering that required buildings to be firm, rigid, and strong, with the expectation that they would remain constant and sound as the ground lurched and rumbled beneath. Whether built without consideration for implacable forces of nature, or misguidedly designed to stand rigid and inflexible, these buildings all ended up in the same scrap heap. ${ }^{1}$

Amidst the rubble, one building stood tall, enduring minimal damage. Frank Lloyd Wright's Tokyo Imperial Hotel stood as a monument to a simple, yet revolutionary, principle: flexibility. ${ }^{2}$ By making his design adaptable-creating a unique floating foundation, rather than using traditional deeply driven piles-Wright's design withstood the earthquake. ${ }^{3}$ Wright understood that in the future, the

1. For more on the Great Kanto Earthquake, see ZEILINGA DE BOER \& DONALD THEODORE SANDERS, EARTHQUAKES IN HUMAN HISTORY: THE FAR-REACHING EFFECTS OF SEISMIC DisRuPTIONS 170-93 (Princeton Univ. Press 2007).

2. Kathryn Smith, Frank Lloyd Wright and the Imperial Hotel: A Postscript, 67 THE ART BULlETIN 296, 301, 309 (1985); CARY JAMES, THE IMPERIAL HOTEL: FRANK LloYd WRIGHT AND THE ARCHITECTURE OF UNITY 18 (1968); FRANK LLOYD WRIGHT, AN AUTOBIOGRAPHY, quoted in JAMES, supra, at 35-46.

3. JAMES, supra note 2, at 18. 
land underfoot would be subject to inexorable yet unpredictable forces of push and pull, shift and shake, threatening the most diligent, but in reality transient, efforts of humankind.

These lessons of flexibility and humility in the face of inevitable change and the unknown are too often ignored in legal doctrines and systems governing the validity and enforcement of American land allocation agreements. ${ }^{5}$ Courts and legislatures have too commonly failed to recognize that the agreements made by parties today creating rights and obligations in land as well as the architecture of today's land transaction record system will control future owners; those solutions of today may be inadequate or harmful to successors who appear in future generations as well as those that come along shortly after the original deal ("proximate successors"). Rigid adherence to the needs and vision of current owners may deny future owners the benefit of free market transactions and personal autonomy that a flexible, high-functioning land transactions system should yield. We of the current generation must consider future generations in two ways. First, the structure and rules of the land transactions systems that we create today cannot unduly favor current owners over the market aspirations of future generations and proximate successors. Moreover, we need to recognize the impossibility of predicting the shifts of the future, by building in the flexibility to permit future generations of land owners-who will likely include our children and grandchildren-to make the decisions that will control their own lives.

Land has played a central role from the time of the earliest civilizations to the current American experience. It has been a source of wealth (and for many millennium the central source of wealth), political power, and social prestige for its owners. People have struggled to own land over the centuries to provide for a better standard of living, social acceptance, and personal satisfaction. Land has been used to advance the human condition, through economic development activities, the creation of living environments, and the preservation of natural areas that support diverse life and inspire the human spirit.

Given the tremendous impact of land on human endeavor, it is not surprising that the ownership and allocation of land rights has

4. Admittedly, these are not qualities usually associated with $\mathrm{Mr}$. Wright.

5. The term "land allocation agreement" is used to refer to a bilateral contract or unilateral instrument transferring all or a portion of the possessory or nonpossessory rights in real property. Examples include deeds, easements, covenants, leases, mortgages, and liens, among others. 
occupied much attention of the political, social, and legal systems over the centuries and throughout the world. The American legal system has developed doctrines across the spectrum of private and public land issues, adopting some from the English tradition but also developing new rules to fit the American context. Reflecting our market economy and political philosophy, land rights-like other non-real property rights such as intangibles, goods, and intellectual property-are created, transferred, and financed in consensual transactions. As an overall guiding principle, U.S. law appropriately validates and enforces arrangements (including land transactions) agreed to by buyers and sellers, on the well-established and proven theory that this will maximize our collective wealth.

Yet, there is something different about land transactions compared to other property interests that requires special attention to land allocation agreements. Because of the ephemeral nature of the underlying asset, contracts relating to non-realty assets have a limited temporal reach. Arrangements about the ownership of an automobile, the scope of warranty coverage, insurance contracts, title and lien rights, and other questions will no longer control going forward when the car is junked. ${ }^{6}$ The subject of the deal is gone, and the contracts related to it disappear. These contracts only bind people who voluntarily took on obligations. There is limited societal interest in such consensual arrangements as they do not bind others. Even if the deal was not a good one in terms of the communal interest in efficient allocation of resources, the bad arrangement has a limited life cycle and soon will disappear.

Land is altogether different, and raises unique issues. First, land lasts forever. Rights to realty commonly are created as perpetual interests, via fee simple transfers, easements, restrictive covenants, and other devices. ${ }^{7}$ Thus, arrangements created by parties to a transaction today can last forever, controlling ownership and use of the realty. This is about creating rights in an asset with far more staying power than an automobile.

As a corollary, the agreement allocating land rights that the buyer and seller reach today will generally bind future owners (and perhaps neighbors) of the subject property. Original parties and proximate successors will be subject to the agreement. Importantly, though, the parcel will continue to exist long after the lives of the current

6. Disputes already in existence will still need to be resolved, but old arrangements will otherwise die.

7. Even interests with limited duration are created to last a long time, such as 100 year ground leases (often renewable) and the standard thirty-year mortgage. 
contracting parties and will be owned by others in the generations to come. Thus, owners in future generations will be constrained in their control of the land and perhaps barred from shifting it to uses that are more beneficial to the owners and society. Contracts for goods rarely bind third parties, while contracts for realty in effect routinely do precisely that. ${ }^{8}$ We as a society have come to understand that current owners can substantially or even irreversibly degrade the natural and ecological attributes of land, impacting future generations. Similarly, we need to recognize that legal arrangements respecting land may also have a long term effect on the property's use and enjoyment. For example, this may result from building and use restrictions in restrictive covenants, the burdens of easements, coownership schemes, and the operation of the recording system.

Finally, land is a limited resource. It is essential to our society and will be vital to the worlds of our children and future generations. While new technologies may allow for more effective utilization and exploitation of land, the total sum of acreage is both finite and static. In addition, as will be developed below, this scarce resource continues to play a unique and critical economic, social, and political role in the United States. Land is not just another asset in our experience, and future generations will need the ability to effectively utilize and manage this unique resource.

Future owners are, therefore, interested parties in the land rights allocation arrangements created by the current generation and in the legal rules and record system that governs and enforces them. First, the structure and rules created today will govern subsequent owners, both those in future generations and proximate successors. Moreover, everything that we know about the natural, commercial, intellectual, and spiritual worlds tells us that change is inevitable, indeed inexorable at times. This is not a normative position about the benefits of change, but merely descriptive of reality over human history. Future generations will be faced with economic, political, and social challenges and opportunities, as well as technological advances and missteps, that are likely beyond our imagination today. They will have to make market decisions to achieve an efficient land allocation and personal satisfaction in light of then extant conditions. They will have to find the balance between individual property rights and the

8. There are some other arrangements that also present the potential for perpetual life and a reach extending to future generations, for example, the corporation. Because of this and other factors, the corporation receives significant statutory, regulatory, judicial, and popular attention, on a range of issues including, among others, governance, accountability, business practices, shareholder rights, and corporate social responsibility. 
collective that suits their times, just as our notions on this issue have changed and re-changed radically over the past half-century. ${ }^{9}$ There is no clear linear path to such choices, the facts and discussions are complex and difficult, and the process and results might look orderly and pre-ordained only with the false vision of hindsight.

Citizens, courts, and legislators of our current generation need to consider the future generations as stakeholders among the usual constituencies as we continue the evolutionary shaping of our doctrines and system of land transactions. While electoral politics and public choice theory (affecting legislators and elected judges) may tell us that it will be difficult to provide a seat at the table for the future generations, ${ }^{10}$ it is our obligation as citizens and parents to do so. As citizens, we continue to be participants in the great American experiment of building a new and better society, and we need to allow the opportunity for future generations to continue in that quest as well. As parents, we are devoted to the raising of our children and grandchildren. We seek to build a better world for them to inherit, a wish that entails our making decisions today that will affect the future that our children will occupy. At times conflicting with this benign paternalistic activity is our desire to empower our children and to make them autonomous adults able to find fulfillment and happiness through their own efforts.

This Article, therefore, focuses on two key issues. The first involves the architecture of the land transactions system and the legal rules that operationalize it. Successor owners-members of future generations and proximate successors as well-deserve to inherit a system that does not favor current interests over theirs when it comes to conflicts in the marketplace. This will require the courts and legislatures to create a system that fairly accommodates present and successor interests. As demonstrated below, this Article suggests reforms to existing rules on the interpretation and enforcement of instruments and aspects of the recording system that unduly favor present owners. By solving general system issues dealing with successors, government can address the legitimate aspirations of future generations and help to ensure generational balance.

9. Consider, for example, the rise in environmental regulation in the 1970 s which imposed limitations on individual landowners, followed in the 1990s by the resurgence of the "property rights" movement. See generally PRIVATE PROPERTY IN THE 21st Century: THE Future OF aN AMERICAN IdEAL (Harvey M. Jacobs ed., 2004) [hereinafter PRIVATE PROPERTY IN THE 2lst CENTURY].

10. On public choice theory, see James M. Buchanan, Constraints on Political Action, in James M. Buchanan \& Richard A. Musgrave, Public Finance and Public CHOICE 107-28 (1999). 
Second, there is the need to provide flexibility for future generations. Perhaps the greatest gift we can give as citizens and parents to the next generations is the power and flexibility to adapt the world we have created for them, and to make course corrections to meet ever-changing needs. We must have a good measure of humility when we attempt to predict the future and impose a vision of land use and rights that will bind coming generations. While in retrospect history might seem inevitable, looking forward, the future is unclear. Human experience is replete with failed attempts to shape the land in the image of current land holders. "The stories of successful land planning for the future are indeed rare enough that they are deserving of celebration."

This Article will argue that in order to achieve this objective of injecting flexibility for future generations, courts should-on rare occasions-deny or limit enforcement of an old land allocation arrangement, or broadly construe such a contract, when the threat to personal autonomy of the current owner must trump strict enforcement of the contractual arrangement. Moreover, the courts and legislatures must preserve the eminent domain doctrine to enable future communities to escape from the all-too-human errors of the past. ${ }^{13}$

11. Consider the story of homesteaders in Eastern Montana:

In 1910, the homesteaders had arrived on the prairie, full of ideas about how to create an ideal rural society on the empty land. In 1995, sitting on the corral fence, with all the conceited wisdom of hindsight, one could see that most of their ideas had been preposterous. The European farm villageeven the Ohio farm village-could never have been transplanted to the dry plains. It wasn't long before the society built by the homesteaders came tumbling down about their ears and forced most of them into a farther western exile.

JONATHAN RABAN, BAD LAND 272 (paperback ed., Vintage Departures 1997).

12. In 1807 a commission was appointed by New York City to plan for the city's future, a time in which Manhattan had barely developed beyond the initial footprint of the city, with much of the land beyond what we now know as 50th Street being virtually unsettled. Daniel OKrent, The Great ForTune: The EPIC Of RockefEller CENTER 8-9 (Viking 2003). The commission laid out a plan with twelve avenues running north and south and 155 numbered streets running east and west through this undeveloped landscape. Id. This plan was "the most courageous act of prediction in Western civilization: the land it divides, unoccupied; the population it describes, conjectural; the buildings it locates, phantoms; the activities it frames, nonexistent." Id. (quoting REM KoOlHAAS, DELIRIOUS NEW YORK 18-19 (Monacelli 1994)).

13. This Article will not directly focus on the asserted obligation of the current generation to future generations to preserve the ecological, natural, or historical attributes of our land or the financial value of real estate. Rather, it focuses on the land transactions systems and legal doctrines related to land agreements, and advocates for equity among the generations with regard to these issues. See infra Section II. 
The overall recommendation of this Article is that courts and legislatures must consciously consider the interests of future generations (and proximate successors where appropriate) when framing rules and remedies related to system operation and flexibility. These decision-makers will need to include the future generations at the table, and protect their ability to seek personal satisfaction through marketplace and collective action.

Section I will analyze the vital economic, social, and political role that land ownership has played in the American experiment. It will demonstrate that legal rules governing land transactions must be carefully drawn by courts and legislatures because of the ongoing importance of land to current and future generations. Section II will examine the imperative of humans to provide for future generations and underscore the need for a land transactions system and doctrines that do not unduly favor current owners over successors. The major themes in American land law-freedom of contract and free alienability-are analyzed in Section III. The Section examines ways to achieve the efficiency and liberty benefits of freedom of contract, and the market promotion and dead hand limitation advantages of free alienability, not only for current owners but also for future generations. It concludes that, first, the architecture of the land transactions system and related legal rules cannot unduly favor current owners over successors. Moreover, it asserts that in rare circumstances the legal arrangements established in the past might not be enforceable if they threaten market functioning and personal autonomy of future generations. Section IV applies these conclusions to five areas of current doctrine and finds that, with a few exceptions, they miss the importance of generation equity and the value of future flexibility. Too often existing law unduly favors current owners over successors, leading to inefficient utilization of land resources, erratic functioning of realty markets, and unacceptable limits on personal choice and autonomy. Section IV also recommends changes in legal rules as a result of this analysis.

\section{LAND OWNERSHIP IN THE AMERICAN EXPERIENCE}

The ownership of land and the drive to acquire it have special importance in America's economic, social, and political arenas, reaching from the Colonial period to the present day. The land transactions system and related rules of law, therefore, must reflect the significance of realty in American life for past and future generations. This Section will trace the role of land ownership in the United States. 


\section{A. A Valuable Commodity}

Although land is no longer the most important source of wealth in the United States-industrialization made intangibles, intellectual property, and other property rights more valuable - the total wealth from real estate holdings remains substantial. ${ }^{14}$ While freedom to pursue their religion was the crucial motivator of the Pilgrims to establish the Massachusetts Bay Colony, ${ }^{15}$ subsequent immigrants to the colonies and then to the United States primarily sought access to land in addition to the benefits of religious and political freedom. ${ }^{16}$ Indeed, Everett Dick notes that "[l] and became the lure that enticed immigrants to America and settlers farther westward."17 Land was scarce in England and other West European countries that supplied the first voluntary immigrants. ${ }^{18}$ Feudal vestiges remained in Europe and an elite class held most of the realty. ${ }^{19}$ In contrast, there was plenty of available land in America, as the claims of the Native Americans were marginalized or abrogated..$^{20}$

Land was economic opportunity for newcomers to America as well as residents moving West during the eighteenth and nineteenth centuries when lands were opened up to settlement. White males could acquire land, on which they created farms, lived and had families, and which could be mortgaged for capital to invest back into the property. ${ }^{21}$ And acquire they did. Some seventy percent of

14. Sonya Salamon, Cultural Dimensions of Land Tenure in the United States, in WHO OWNS America? SOCial CONFlict Over Property Rights 159, 163 (Harvey M. Jacobs ed., 1998); see Charles C. Geisler, Land and Poverty in the United States: Insights and Oversights, 71 LAND ECON. 16, 18 (1995) (arguing that there is still a modern connection between poverty and land ownership).

15. Nathaniel Philbrick, Mayflower 4-5, 129 (Penguin 2006); see James W. Ely, Jr., The Guardian of Every Other Right: A Constitutional. History of Property RIGHTS 10 (2d ed. 1998) (asserting that land was also a partial motivation).

16. Harvey M. Jacobs, Introduction, in Private Property IN THE 21st Century, supra note 9, at 4; Henry G. Bennett, Land Independence: American's Experience, 27 LAND ECON. 379, 380 (1951); Stanley Lebergott, The Demand for Land: The United States 1820-1860, 45 J. ECON. HIST. 181, 184 (1945). See generally Michael JonesCorrea, Reshaping the American Dream, in THE NEW Suburban HISTORY 183-204 (Kevin M. Kruse \& Thomas J. Sugrue eds., 2006).

17. Everett Dick, THE Lure of THE LANd ix (1970); ANNe MaCkin, Americans AND THEIR LAND: The House BuIlt ON ABUNDANCE 34-35 (2006).

18. LaWrence M. Friedman, A History of American Law 24 (3d ed. Touchstone 2005).

19. Bennett, supra note 16 , at 379 ; Dick, supra note 17 , at ix.

20. FRIEDMAN, supra note 18 , at 24.

21. Hernando de Soto, The Mystery of Capital 113-48 (Basic Books 2000). See generally WillaRd STERNE RANDALl, ThOMAS JEFFERSON: A LiFe 288-89 (Henry Holt 1993) (detailing Jefferson's plans to distribute unappropriated lands to independent farmers); Naomi R. Lamoreaux, Did Insecure Property Rights Slow Economic Development? Some Lessons from Economic History, 18 J. POL'Y HIST. 146, 148-49 (2006) (describing scholars questioning property rights as a necessary precondition for economic development). 
freemen owned land by the time of the American Revolution. ${ }^{22}$ Subsequently, the federal government disposed of much of the expansive territory that it had acquired in the West from England and then through the Louisiana Purchase. Unlike European powers, the U.S. government sought to limit the amount of land that it held and divested itself of huge quantities of land. ${ }^{23}$ Thus, land was conveyed without consideration as a "dowry" to states when they were admitted to the Union, and to local governments as well. ${ }^{24}$ The federal government gifted land to soldiers from the Revolutionary and Mexican Wars and others who had performed important services. $^{25}$

During the nineteenth century, the federal government sold western lands to settlers at bargain prices or gifted the land, charging only nominal fees for registering the claims. ${ }^{26}$ Representatives from the plains states, in an effort to increase population and markets, sent recruiters to the eastern United States and to Europe to recruit new settlers with the lure of free land. ${ }^{27}$ Railroads advertised "Free Homes for the Millions" in order to grow the demand for the shipping of agricultural products. ${ }^{28}$ Lawrence Friedman has observed that " $[\mathrm{i}] \mathbf{n}$ land lay the hope of national wealth; for countless families, it was their chance to make some money." ${ }^{29}$ Land was also viewed by some as essential to the successful integration of the freed AfricanAmerican slaves into American economic, social, and political life, but the promise of "forty acres and a mule" turned out to be hollow.

Because of land's paramount economic importance to Americans, it was quickly treated by the population as a commodity, something to be bought and sold in the marketplace, free of the feudal restrictions of Europe. ${ }^{31}$ Attempts to impose feudalism in the United States failed in all but a few cases, and those that succeeded were short-lived. ${ }^{32}$ The view of land as a commodity was a key factor underlying the federal government's decision to dispose of land to individual

22. MACKIN, supra note 17 , at 26-27.

23. FRIEDMAN, supra note 18, at 168-69.

24. DICK, supra note 17, at 120; FRIEDMAN, supra note 18, at 169.

25. DICK, supra note 17 , at 121 .

26. Id. at $123-26,139$.

27. Id. at 158 .

28. Id. at 175; see RABAN, supra note 11, at 272 (describing the failure of farms on government disposed tracts in eastern Montana during the early twentieth century).

29. FRIEDMAN, supra note 18 , at 171 .

30. Eric Foner, Reconstruction Revisited, 10 REVIEwS IN AM. HIST. 82, 86 (1982).

31. Morton J. Horwitz, The Transformation of AMERICAN LAW 1780-1860 31 (Harvard Univ. Press 1977).

32. See FRIEDMAN, supra note 18, at 26-27 (describing attempts to establish quitrents and the end of the New York patroon system). 
citizens, rather than to hold it in a static state. ${ }^{33}$ Moreover, people sought land not only for owner-occupied farms but also for commercial activities such as mining, town development, transportation hubs, lumber, and dams. ${ }^{34}$ Land was actively traded in an open market. As a result, innovations in the law of land transactions-such as the creation of the recording system so that buyers could pay in confidence that they would receive good title and streamlined forms of deeds-were instituted to support this trade in land. ${ }^{35}$ Other traditional gap-filling rules were revised to accommodate development over status quo land holding. ${ }^{36}$

\section{B. Social Belonging}

Land ownership helped to shape American society. Unlike the experience in the nobility-dominated countries from which the immigrants came, many of the new Americans owned land. The United States became a country of the landed "middle class," the landed gentry. The new American paradigm was that of the small landowner, and the government's liberalization of its policy on disposing of public lands was but one example of its obeisance to this emerging, potent political bloc. ${ }^{38}$ Furthermore, acquiring land was a means to a higher social status and a symbol of financial stability. ${ }^{39}$ An American could experience social mobility through acquisition of land, moving from a tenant to becoming the owner of increasingly larger tracts of farmland. ${ }^{40}$ Buying land was an especially important means to improve social status for immigrants to the United States. ${ }^{41}$

While there certainly were emotional attachments to individual parcels of property, Americans born in the United States and abroad

33. See id. at 168. But see Gregory S. Alexander, Commodity and Propriety: COMPETING VISIONS OF PROPERTY IN AMERICAN LEGAL THOUGHT 1776-1970 3-4 (1997) (arguing that property serves an additional role in society besides market exchanges).

34. Dick, supra note 17 , at $\mathrm{x}$.

35. FRIEDMAN, supra note 18 , at $27,173-75$.

36. See HoRwITZ, supra note 31, at 54-56 (describing the relaxation of English waste law to permit the cutting of timber in the United States).

37. Defining "middle class" is difficult, and can be seen as an incorporation of income, occupation, and life outlook. Clifford EdWARd Clark, JR., THE AMERICAN FAMILY HOME 1800-1960 xii-xiii (1986).

38. FRIEDMAN, supra note 18, at 168, 177; see Richard Harris \& Chris Hamnett, The Myth of the Promised Land: The Social Diffusion of Home Owmership in Britain and North America, 77 ANNALS OF THE ASS'N OF AM. GEOGRAPHERS 173, 174 (1987) (describing home ownership as a signal of the emergence of immigrants into the lower middle class).

39. ClARK, supra note 37 , at 239 ; DICK, supra note 17 , at 1.

40. Salamon, supra note 14 , at $162-63$.

41. Id. at 162 . 
moved constantly as they homesteaded lands and subsequently sold the properties to migrate to even greener pastures further west. ${ }^{42}$ One did not spend one's whole life on the same feudal estate. The optimistic nature of the American people today and the current mobility of the American population, in search of new opportunities, may well be a legacy of our experience with land acquisition. ${ }^{43}$ Additionally, the abundance of land in the United States, compared to the Europe left behind by the immigrants, may have led to a "bigger is better" mentality in economic and civic life."

Rampant land speculation and occasional scamming was a part of the American scene. ${ }^{45}$ Walter McDougall has asserted that Americans in the period to the mid-nineteenth century were "hustlers"-in the "positive sense" of being "builders, doers, go-getters, dreamers, hard workers, inventors, organizers, engineers, and a people supremely generous." ${ }^{46}$ Those attributes continue to support Americans' faith in themselves and the American system of ordered liberty, providing the recipe for personal success and world leadership. ${ }^{47}$ Acquiring and developing the vast American wilderness was part of that equation. ${ }^{4}$

Land is also the physical locus of the American family home. The American family home has played a large role in our social fabric, and the family unit has been seen as virtually synonymous with the physical structure of the house. ${ }^{49}$ To be sure, the American family home today is different than in the eighteenth century and current issues need to be addressed: the definition of family has been historically restrictive and is fortunately being re-thought to some extent; ${ }^{50}$ there has been a lack of variety in home design to accommodate different family living arrangements; ${ }^{51}$ there is a serious

42. DiCK, supra note 17 , at 354 .

43. MACKIN, supra note 17 , at 194.

44. Salamon, supra note 14 , at 160 .

45. FRIEDMAN, supra note 18, at 27, 176; Lebergott, supra note 16, at 194-96.

46. Walter A. McDougall, Freedom Just Around THE Corner: A New AMERICAN HISTORY 1585-1828 7 (Harper Collins 2004).

47. Id. at $4-5,7$.

48. Id. at 424,460 .

49. See ClaRK, supra note 37 , at $\mathrm{xi}$ (describing Alexis de Tocqueville's observations of the importance of home life in America).

50. See Everett D. Dyer, The American Family: Variety and Change 16 (1979); Michael Gordon, The American Family: Past Present, and Future 25-28 (1978) (analyzing the criticisms of George P. Murdock's classic definition of family); SAR A.

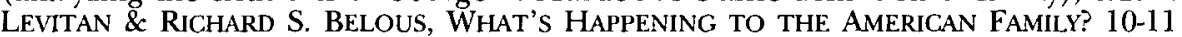
(1982); WHITE HOUSE CONFERENCE ON FAMILIES, A SUMMARY: LISTENING TO AMERICA'S FAMILIES (1980); Gerald Korngold, Single Family Use Covenants: For Achieving A Balance Between Traditional Family Life and Individual A utonomy, 22 U.C. DAvis L. REV. 951, 95253 (1989) [hereinafter Korngold, Single Family].

51. See DOlORES HAYDEN, REDESIGNING THE AMERICAN DREAM 13 (paperback ed. 1986). 
threat that home ownership, even rental housing, has become unaffordable for significant segments of our society, placing this facet of the American dream beyond the reach of too many; ${ }^{52}$ and suburban design has led to distancing people from work, entertainment areas, and stores, with some criticizing ${ }^{53}$ and others lauding this state of affairs. ${ }^{54}$ Yet, the American family home remains a foundation of our society: often representing a family's greatest economic investment and asset and providing a source of stability in difficult economic times; providing a haven from the hubbub of the outside worlds of work and public affairs, especially in a mobile society; offering opportunities for personal satisfaction through selfactualization and family interactions; presenting a forum for the inculcation of values in children that will support civic discourse and deeds and the realization of personal dreams; and allowing an opportunity to create a pleasing aesthetic. ${ }^{55}$ The notion, design, and values associated with the American family home have evolved over the centuries, reflecting economic, social, and psychological developments. $^{56}$ Importantly, one can exercise free choice and individual autonomy in selecting a home, from a range of styles, locations, living arrangements, and communal relationships. ${ }^{57}$

52. There are many asserted causes for this problem: large lot zoning, tax subsidies to upper income and commercial developments, lack of an adequate social safety net, among others. See generally Robert W. Burchell \& William R. Dolphin, Affordable Housing and Redevelopment: Quantifying Affordable Housing Needs and Responses in New York City, 22 GA. ST. U. L. REv. 751 (2006); Sagit Leviner, Affordable Housing and the Role of the Low Income Housing Tax Credit Program: A Contemporary Assessment, 57 TAX LAW. 869 (2004); Brian W. Ohm \& Robert J. Sitkowski, Integrating New Urbanism and Affordable Housing Tools, 36 URB. LAw. 857 (2004). Moreover, the recent increases in foreclosures of "subprime" mortgages is ending the short-lived home ownership of people with lower economic means. Erik Eckholm, Foreclosures Force Suburbs to Fight Blight, N.Y. TIMES, Mar. 23, 2007, at A1.

53. See, e.g., Andres DuAny, Elizabeth Plater-Zyberk \& JefF Speck, Suburban Nation: THE Rise of SPRAWl and THE DECline OF THE AMERICAN DREAM 115-33 (paperback ed. 2001) (asserting that sprawl destroys communal life and leads to less economic opportunity).

54. See, e.g., Robert Bruegmann, Sprawl: A Compact History (2005) (arguing that sprawl is not a recent phenomenon and that it brings benefits in terms of mobility and democratization).

55. See ClARK, supra note 37, at 239-41 (chronicling the steadfast importance to Americans of owning a single-family dwelling).

56. See MARGaret MARSH, Suburban Lives (1990) (describing changes in gender roles, parent-child relationships, and other factors).

57. Gerald Korngold, Resolving the Flaws of Residential Servitudes and Otwners Associations: For Reformation Not Termination, 1990 WIS. L. REv. 513, 519-20 (1990) [hereinafter Korngold, Owners Associations]. 


\section{Land and Democracy}

As a political matter, land ownership has been important. Initially it was a pre-requisite to voting and holding office. ${ }^{58}$ Although these requirements ultimately fell away, land ownership remained vital to the philosophical underpinnings of Revolutionary political thought and the formation of the new country. Property ownership was seen as helping to ensure freedom, since one relying on government largesse would be unwilling to challenge governmental decisions. An owner of a guaranteed property interest, however, would be confident to take on authority. This clearly would benefit the individual owner, but more importantly the presence of a large number of land owners would serve as a check on an overreaching government. $^{59}$ Jefferson's yeoman farmer would serve as the foundation of American democracy. ${ }^{60}$ Under this view, political freedom is dependent on property ownership. ${ }^{61}$

Jefferson's vision of the independent, agrarian landholder never became the dominant economic reality in the United States. ${ }^{62}$ This did not deny the power of Jefferson's vision about democratic participation by freeholders to the Founders or in centuries to follow. Additionally, it appears that land ownership did indeed play a role in developing democracy among the new immigrants as the years passed. $^{63}$

58. FRIEDMAN, supra note 18 , at 167 n.1.

59. See TOM Bethell, The Noblest Triumph: Property and Prosperity Through THE AGES 3 (St. Martin's Griffin 1998); ELY, supra note 15, at 17-18 (describing property ownership as a means to maintain political liberties); RICHARD PIPES, PROPERTY AND FREEDOM 117 (Alfred A. Knopf 1999). See generally Cass R. Sunstein, On Property and Constitutionalism, 14 CARDOZO L. REV. 907 (1993).

60. HAYden, supra note 51, at 19; PRIVATE PROPERTY IN THE 21st CentuRY, supra note 9, at 5; Lisa Krall, Thomas Jefferson's Agrarian Vision and the Changing Nature of Property, $36 \mathrm{~J}$. EcON. Issues 131, 131 (2002); Salamon, supra note 14, at 163. Jefferson's agrarian vision later influenced the creation of suburbs in the late nineteenth and twentieth centuries as havens from reviled urban areas and populated by "virtuous citizens." MARSH, supra note 56, at 4-7 (quoting the nineteenth-century architect Andrew Jackson Downing, ANDREW JACKSON DOWNING, The ARChITECTURE of COUNTRY Houses 270 (reprint, Dover Publ'ns 1969) (1850)); see JOHN R. STILGOE, BORDERLAND: ORIGINS OF THE AMERICAN SUBURB, 1820-1939 94-95 (Yale Univ. Press 1988) (explaining how the country ideology influenced colonial political theory and shaped the Federal Constitution); see also Kevin M. Kruse \& Thomas J. Sugrue, Introduction: The New Suburban History, in THE NEw Suburban HISTORY 1 (Kevin M. Kruse \& Thomas J. Sugrue eds., 2006) (describing the importance of suburban voters in current political campaigns).

61. Jefferson's vision supported the sale of the vast trove of federal lands, in small units, to individual owners. Lebergott, supra note 16, at 205-06.

62. See Krall, supra note 60 , at 133 (describing how the industrial revolution changed the meaning and purpose of private property ownership from Jefferson's original vision).

63. R. Cole Harris, The Simplification of Europe Overseas, 67 ANNAIS OF THE ASSOCIATION OF AMERICAN GEOGRAPHERS 469 (1977). 
In the twenty-first century, America still offers its population of over 300 million people vast amounts of open, relatively undeveloped land. Of the approximately 1,900 million acres in the forty-eight contiguous states, over $84 \%$ is forests outside of parks, grassland pasture and range, or cropland. ${ }^{64}$ There is, however, a crunch in urban areas, which are defined as including cities and surrounding suburbs. ${ }^{65}$ Estimates show that $80 \%$ of Americans currently reside in urban areas, while only $5 \%$ lived in such areas at the time of the founding of America. ${ }^{66}$ Yet urban lands comprise only $3 \%$ of the continental American lands. ${ }^{67}$ Although the overall land mass may be huge, the population has been drawn by jobs, lifestyle, and personal choice to concentrated urban/suburban areas. This crowding has made questions about allocation of land rights between current contestants and the next generation all the more complex, and critical, to resolve effectively.

\section{THE INTERGENERATIONAL COMPACT}

Human experience and thought is replete with manifestations of concern for, and dedication to the welfare of, future generations. Attributed to everything from the Darwinian imperative to abstract political philosophy, humans have sought to advance the human condition for their offspring. This phenomenon is so well understood across the range of cultures and times that it hardly needs proof or elaboration. This Section will describe a few key expressions in the American context. These manifestations support the thesis of this Article that current owners have a duty to future generations with respect to the land transactions system and legal doctrines.

The obligation of the current generation to future generations has a large economic and wealth component. First, the law of inheritance (i.e., intestate succession in the absence of a will) in the various states provides for a share for the children of the decedent (in addition to a share for the surviving spouse). ${ }^{68}$ This child's share

64. Ruben N. Lubowski, Marlow Vesterby, Shawn Bucholtz, Alba Baez \& MichaEl J. Roberts, Major USES OF LAND IN THE UNITEd STATES, 20022 (U.S. Dep't Agriculture 2006) [hereinafter USDA REPORT], available at http:/ /www.ers.usda.gov/ publications/EIB14/eib14.pdf.

65. See William A. Fischel, The Economics of Zoning LaWs: A Property Rights APPROACH TO AMERICAN LAND USE CONTROLS 4 (1985) (citing data compiled by $\mathrm{H}$. Thomas Frey in 1979 showing higher population density in urban areas).

66. MARSH, supra note 56 , at 1 .

67. USDA REPORT, supra note 64 , at 2.

68. UNIF. Probate Code: INTESTacy, Wills and Donative Transfers $\$ \S 2-102,2-$ 103 (1990). 
will pass to that child's next generation of living issue of the decedent if the child predeceased the decedent. ${ }^{69}$ Intestate transfer of wealth to the next generation reflects the common belief of Americans as well as the patterns in wills executed by testators over the generations. ${ }^{70}$ Concern for providing income security to the next generation dates back to feudal England and the nobles' insistence that the King recognize the fee simple absolute as an inheritable estate. $^{71}$ It is true that under the principle of freedom of testation a testator may disinherit a child $;^{72}$ in the absence of such an expressed, empirically unusual preference, however, the law presumes support by the current generation of the next.

Moreover, a longstanding American value has been to leave the next generation economically better-off than the current and prior generations. ${ }^{73}$ Intergenerational caring and support within families is generally attributed to altruism. ${ }^{74}$ Moral and instinctive motivation to care for future generations remains strong today. ${ }^{75}$ Even economicsbased approaches find that altruism plays a role-the fact that a parent feels happy by sharing with a child (and the child's children) is a motivation for giving to future generations. ${ }^{76}$ Intergenerational continuity has also played a crucial role in perpetuating society and

69. Id. \$2-106.

70. Ashbel Green Gulliver et al., Gratuttous Transfers: Wills, Intestate SUCCESSION, TRUSTS, GIFTS, FUTURE INTERESTS, AND ESTATE AND GIFT TAXATION 60-61 (3d ed. 1985).

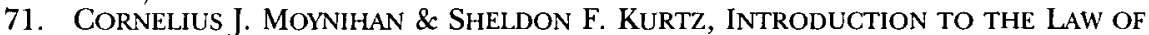
REAl Property 35-37 \& n.4 (3d ed. 2002); A. JAMES CASNeR, 1 AMERICAN LaW OF PROPERTY \$ 1.5 (1952).

72. Jesse Dukeminier et al., WiLls, Trusts, AND Estates 466-68 (7th ed. 2005). The Uniform Probate Code protects unintentionally omitted children. UNIFORM PROBATE CODE: INTESTACX, WILIS AND DONATIVE TRANSFERS § 2-302.

73. Robert A. Harootyan \& Vern L. Bengtson, Intergenerational Linkages: The Context of the Study, in INTERGENERATIONAL LiNkAGES: HIDDEN CONNECTIONS IN AMERICAN SOCIETY 1 (Robert A. Harootyan \& Vern L. Bengston eds., 1994). This may be understood as well in the context of the American credo of Progress, adhered to by Jefferson. WILlard STERNE RANDALl, THOMAS JEFFERSON: A LifE 204-05 (Henty Holt 1993).

74. Dennis P. Hogan, David J. Eggebeen \& Clifford C. Clogg, The Structure of Intergenerational Exchanges in American Families, 98 AM. J. Soc. 1428, 1431 (1993); John R. Logan \& Glenna D. Spitze, Self-Interest and Altruism in Intergenerational Relations, 32 DEMOGRAPHY 353, 354-56 (1995).

75. Partha Dasgupta, Karl-Goran Maler \& Scott Barrett, Intergenerational Equity, Social Discount Rates, and Global Warming, in DISCOUNTING AND INTERGENERATIONAL EQUITY 51, 55 (Paul R. Portney \& John P. Weyant eds., 1999).

76. Logan \& Spitze, supra note 74, at 355; see Dasgupta, Maler \& Barrett, supra note 75 , at 56 . Some economists find that support is given to motivate future reciprocal support. Hogan, Eggebeen \& Clogg, supra note 74, at 1431. 
preparing the next generation to meet the demands that are eventually placed upon them."

Some have claimed that intergenerational inequity has developed with the older population accumulating wealth and consuming benefits at the expense of younger people, and that this has led to intergenerational enmity and jealousy by the young. ${ }^{78}$ Studies, however, do not support either the inequity or the enmity hypotheses and instead show little intergenerational anger or perceptions of inequity. $^{79}$ Generational solidarity among families has remained constant despite the challenges and changes of the modern world, and may have even increased because the older generation is living longer and available to bind with children, grandchildren, and greatgrandchildren. ${ }^{80}$ Empirical studies show strong agreement with the norm of parental obligation to adult children. ${ }^{81}$ Indeed the entire sustainability movement can be seen as the current generation recognizing and undertaking an obligation to future generations with respect to the environment. ${ }^{82}$ Moreover, studies maintain that there is no actual increase in intergenerational tensions despite popular claims to that effect. Existing levels of tension cannot be traced to personal self-interest and concerns by those who bear the costs of support of another generation. ${ }^{83}$ Thus, the value of providing a better standard of living for the next generations remains strong.

There is also a dimension of political and moral theory involved in intergenerational relations. Jefferson's assertion that "earth belongs

77. Joan Aldous, The Consequences of Intergenerational Continuity, 27 J. MARRIAGE \& FAM. 462, 467 (1965).

78. Susan A. Macmanus, Young v. Old: Generational Combat in the $21 \mathrm{st}$ CentuRY 149-50 (1996).

79. See Robert A. Harootyan \& Vern L. Bengtson, supra note 73, at 6-7 (stating that national survey data does not support the contention that there is animosity toward older generations by younger ones).

80. See Leora Lawton, Merril Silverstein \& Vern L. Bengtson, Solidarity Between Generations in Families, in INTERGENERATIONAL LINKAGES: HIDDEN CONNECTIONS IN AMERICAN SOCIETY, supra note 73, at 19 (noting findings by contemporary surveys on intergenerational relations that suggest intergenerational bonds are growing stronger).

81. See id. at 36-37 (describing survey data showing attitudes of individuals with varying characteristics toward parental obligations to children).

82. See generally FaIRnESS AND Futurity: EsSAYS ON ENVIRONMENTAL SUSTAINABILITY AND Social Justice (Andrew Dobson ed., 1999); Talbot Page, On the Problem of Achieving Efficiency and Equity, Intergenerationally, 73 LAND ECON. 580 (1997) (discussing sustainability).

83. See Mark Schlesinger \& Karl Kronebusch, The Sources of Intergenerational Burdens and Tensions, in INTERGENERATIONAL LINKAgES: HIDDEN CONNECTIONS IN AMERICAN SOCIETY, supra note 73, at 185, 207; Logan \& Spitze, supra note 74, at 362. But see MACMANUS, supra note 78, at 173-74 (finding that all generations prefer tax policies favorable to them). 
in usufruct to the living" ${ }^{84}$ demonstrates a belief that each generation is bound to allow its successors the freedom to make their own political choices. ${ }^{85}$ Additionally, future generations must be left free from debt as past obligations would prevent them from enjoying true political freedom and one's own property. ${ }^{86}$ Rawls has posited that "[e]ach generation must not only preserve the gains of culture and civilization, and maintain intact those just institutions that have been established, but it must also put aside in each period of time a suitable amount of real capital accumulation." ${ }^{87}$ It has also been argued that the current generation has a moral obligation to leave future citizens greater basic liberties and a decent society; though this might require a decreased standard of living over current levels, it is claimed that overall welfare will increase. ${ }^{88}$

\section{COMPETING THEMES IN AMERICAN LAND LAW}

Earlier Sections have demonstrated the centrality of land in the American experience as well as the norm of dedication by the current generation to future descendants. This Section will analyze two major themes appearing across the broad range of real property law-"freedom of contract" and "free alienability." The values and policies inherent in these two fundamental, and sometimes competing, concepts must be reflected in the land transactions system and related doctrines in order to maximize the welfare of not only current owners but also future generations. An exploration of contract and alienability will provide guidance for courts and legislatures designing system architecture and legal rules that will fairly accommodate present and successor owners and that will preserve for future generations the benefit of market exchanges and personal autonomy.

84. Herbert Sloan, The Earth Belongs in Usufruct to the Living, in JEFFERSONIAN LEGACIES 281 (Peter S. Onuf ed., Univ. Press of Va. 1993).

85. Id. at 281; see Gregory S. AlEXANDER, COMMODITY AND PROPRIETY: COMPETING VISIONS OF PROPERTY IN AMERICAN LEGAL THOUGHT 1776-1970 26-27 (U. Chi. Press 1997) (explaining Jefferson's doctrine of "political relativism," which gives each generation freedom from debt incurred by previous ones).

86. See Sloan, supra note 84 , at 283 (describing Jefferson's disapproval of the debts of past generations burdening the future enjoyment of property).

87. JOHN RAWLS, A THEORY OF JUSTICE 252 (rev. ed. Belknap Press 1999).

88. See Wilfred Beckerman, Sustainable Development and our Obligations to Future Generations, in FAIRNESS AND FUTURITY: ESSAYS ON ENVIRONMENTAL SUSTAINABILITY AND SOCIAL JUSTICE, supra note 82, at 71, 86-87 (describing environmental and human rights related reasons for the improvement of society for future generations). 
"Freedom of contract" (and related terms such as "freedom of testation") focuses on the initial parties to a real estate transaction and demonstrates a firm belief in upholding consensual market transactions. On the other hand, the "policy favoring free alienability of land" (and related terms such as a "policy against restrictions on land" or a "policy against restraints on alienation") concentrates on future owners of the subject land and sometimes rearranges deals of current parties to prevent possible negative effects on generations to come. Freedom of contract generally embraces a laissez faire approach, while decision-makers are willing to be interventionist under the free alienability doctrine. The following Section will examine these two essential ideas in the context of accommodating multiple generations of owners.

\section{A. Freedom of Contract}

Freedom of contract incorporates various concepts, all of which support the enforcement of agreements allocating rights in real estate, whether involving a conveyance of a full fee simple absolute or the carving out of a lesser possessory or non-possessory interest. Such consensual arrangements should be enforced as a general matter because of considerations of efficiency and liberty. The opportunity to reap the benefits of market-based transactions should be made available to current and future players alike.

\section{Efficiency}

\section{a. Market benefits}

The enforcement of freely-made contracts involving land rights serves to achieve an efficient allocation of our limited land resources. Through voluntary market transactions, property rights end up in the hands of those who most value them and who will best utilize them. ${ }^{91}$ This means that the collective's overall total of land benefits will be increased. Consensual transfers of partial interests in property also

89. See, e.g., Sinclair Ref. Co. v. Watson, 65 So. 2d 732, 733 (Fla. 1953), cert. denied, 346 U.S. 872 (1953); Crowell v. Shelton, 948 P.2d 313, 313 (Okla. 1997); Benton v. Bush, 644 S.W.2d 690, 691 (Tenn. Ct. App. 1982).

90. For cases referring to unrestricted use of land, see, e.g., Univ. Hills, Inc. v. Patton, 427 F.2d 1094 (6th Cir. 1970); Hines v. Heisler, 439 So. 2d 4 (Ala. 1983); Bachman v. Colpaert Realty Corp., 194 N.E. 783 (Ind. Ct. App. 1935); Blevins v. Barry-Lawrence County Ass'n of Retarded Citizens, 707 S.W.2d 407 (Mo. 1986). For cases referring to restraints on alienability, see, e.g., Mountain Springs Ass'n v. Wilson, 196 A.2d 270 (N.J. Super. Ct. Ch. Div. 1963); Cain v. Powers, 668 P.2d 300 (N.M. 1983); Eagle Enters. v. Gross, 349 N.E.2d 816 (N.Y. 1976).

91. Richard A. Posner, Economic Analysis of Law 9-10 (6th ed. 2003). 
serve to efficiently allocate land, as the purchaser is allowed to buy only the particular rights she wants in a parcel. ${ }^{92}$ The purchaser does not have to "overinvest" in the property to acquire full ownership when partial rights are all that she desires, and she can devote her remaining dollars to other uses. For example, if A wants access to a public highway on the other side of neighbor B's property (in addition to the access that $\mathrm{A}$ already has to local roads), A does not have to buy full fee simple rights but can acquire an easement over B's land for a far lesser price. Meanwhile, B is happy to have the extra dollars which $\mathrm{B}$ values more than the bother of having $\mathrm{A}$ occasionally drive over his land. Similarly, the "seller" of a partial interest does not have to part with more property rights than needed to accomplish the seller's specific goal. Thus, the owner of a parcel who seeks to raise capital for an investment in another business venture does not need to sell a fee in his land, but can borrow the investment funds and give a mortgage in his parcel to the lender to secure repayment of the loan.

More complex land allocation arrangements can bring additional benefits. For example, a regime of servitudes $^{93}$ in a residential development creates mutual benefits and burdens among the parcels. While subjecting an individual lot to a building and use restriction (e.g., a "residential only" limitation) might lower the value of that lot, the fact that the other parcels are similarly bound brings offsetting benefits to the burdened property. ${ }^{94}$ Moreover, these subdivision developments often have amenities (e.g., a swimming pool) held in common by the owners or held by an entity with each of the lots having an easement of use. ${ }^{95}$ This is efficient as well, since owners only have to pay for a fractional part of the costs of the pool (and they might not have been able to afford one on their own) and owners satisfied with a communal pool do not have to spend additional resources to build a private one. Consensual real property

92. Robert Ellickson, Alternatives to Zoning: Covenants, Nuisance Rules, and Fines as Land Use Controls, 40 U. CHI. L. REv. 681, 713-14 (1973); Uriel Reichman, Toward a Unified Concept of Servitudes, 55 S. CAL. L. REv. 1177, 1231, 1234 (1982); see Alby v. Banc One Fin., 82 P.3d 675, 681 (Wash. Ct. App. 2003) ("No public interest would be served by depriving [sellers] of the right to convey a determinable fee at a fraction of the value of the unconditional fee.").

93. This is the term used by the Restatement (Third) of Property (Servitudes) to include real covenants, equitable servitudes, and easements. RESTATEMENT (THIRD) OF PROP. \$ 1.1 (2000).

94. See, e.g., Adult Group Props., Ltd. v. Imler, 505 N.E.2d 459, 464 (Ind. Ct. App. 1987) (noting that restrictive covenants are designed to increase the value of benefited land); Rofe v. Robinson, 329 N.W.2d 704, 707 (Mich. 1982) (explaining how zoning restrictions act to preserve valuable "property rights").

95. Korngold, Owoners Associations, supra note 57, at 517. 
arrangements lead to beneficial allocation of our limited land rights. Recognizing this principle is of special relevance in the American context where land from early on was seen as a key commodity to be bought and sold in the marketplace and a source of individual and national wealth. ${ }^{96}$

People will not likely enter such efficiency maximizing transactions unless they are confident that the legal system will enforce them. ${ }^{97}$ Thus, as a general matter, courts should, and do, enforce real property agreements like other contracts. ${ }^{98}$ Moreover, efficiency maximizing transactions will also benefit a successor to the ownership of the initial contracting party. For example, just as A was benefited by having an easement over B's land to reach the public highway, the successor owners of A's parcel will also be advantaged by having that access. Future generations, therefore, can continue to benefit as a general matter by the enforcement of prior land allocation agreements. They will also benefit by a strong legal enforcement of market transactions, since they too will want to be sure that the arrangements they themselves make in light of future needs and conditions will also be enforced. And if $\mathrm{B}$ no longer wants to be burdened by the easement, $\mathrm{B}$ can bargain with $\mathrm{A}$ to find a price that A will accept to release the easement-there is no impediment to a market exchange. These various transactions promote effective use of our finite land resources, a vital public policy in light of the high population concentration in urban areas. ${ }^{99}$

Therefore, there are great benefits for both current and successor owners to be attained by enforcement of land allocation agreements. These advantages can be guaranteed through legal rules and doctrines that enforce such arrangements and also by maintaining a land transactions system that validates and reinforces market transactions.

\section{b. Differences with traditional contract}

Land allocation agreements vary, however, from typical contracts for goods and intangibles in several important ways. These differences stem from the perpetual nature of land use allocation

96. See supra Section I .

97. DE SOTO, supra note 21 , at 62.

98. See, e.g., Seabrook Homeowners Ass'n v. Gresser, 517 A.2d 263 (Del. Ch. 1986), affd, 538 A.2d 113 (Del. Super. Ct. 1988); Sun Valley Ctr. for Arts and Humanities, Inc. v. Sun Valley Co., 690 P.2d 346 (Idaho 1984); J.T. Hobby \& Son, Inc. v. Family Homes, Inc., 274 S.E.2d 174 (N.C. 1981).

99. See supra Section I.C (discussing the high population density in urban areas caused by job and lifestyle opportunities). 
agreements and raise questions about the applicability of bilateral contract theory and solutions when future generations are involved.

First, parties negotiate face-to-face in a traditional bilateral contract, exchanging promises directly. But how does a next generation owner become bound since (except in an unusual case) he does not directly agree to be bound? And for that matter, how does the benefit of the promise move down to a successor in the absence of a specific assignment? Traditional contract theory is insufficient to move the benefits and burdens of land agreements down to future actors.

Property law, therefore, has distinctive theories and devices to tie future owners who did not specifically assent to past arrangements. How does this happen? Essentially the successors are bound through presumed intent based on notice, even though the law might offer some other technical doctrinal explanation. If a purchaser takes land that is the subject of a prior agreement and the purchaser has notice of the previous interest, the purchaser will be bound in such cases; ${ }^{100}$ if there is no notice, then the purchaser will take ownership free and clear of prior interests (with some exceptions). ${ }^{101}$ Thus, a prior mortgagee who has recorded its lien will retain the lien against the land and can foreclose if a purchaser fails to pay off the mortgage as per its terms; ${ }^{102}$ a buyer of property who has notice of a prior lease receives only the landlord's reversionary estate in the property and the leasehold estate is not affected, applying the matrix of common law present and future estates; ${ }^{103}$ and the purchaser of a property bound by a restrictive covenant is liable at law and in equity for breaching the covenant under the theory of "covenants running with the land" if the purchaser has notice, and buyer of a lot benefited by

100. There are three types of notice: actual, record (a.k.a. constructive) or inquiry (a.k.a. inspection). A. JAMES CASNER ET AL., CASES AND TEXT ON PROPERTY 749 (5th ed. 2004).

101. For example, some short-term leases do not have to be recorded to bind successors to the landlord. See, e.g., N.Y. REAL PROPERTY LAW $\$ \S 290(3), 291$ (McKinney 2006). Mechanics liens in some states can be filed after the purchase of property and will relate back to a prior date and bind the new owner (for special policy reasons to protect subcontractors on construction projects). See 2 GRANT S. Nelson \& Dale A. Whitman, Real Estate Finance Law 191-92 (4th ed. 2002).

102. Gerald Korngold \& PaUl Goldstein, Real Estate Transactions: Cases and Materials ON LaND Transfer, Development and Finance 419-27 (4th ed. 2002). Courts distinguish between a purchaser who "assumes" a mortgage (i.e., makes a direct promise to the mortgagee to be personally liable on the debt) and one who only takes "subject to" the mortgage (i.e., where there is no promise by the purchaser, and the mortgagee can only foreclose against the land to make good on the debt and cannot hold the buyer personally).

103. See CASNER ET AL., supra note 100, at 319-20, 403-04 (introducing fee simple and lesser estates within the estates system). As noted, supra note 101, there are exceptions for short-term leases. 
the covenant can enforce it even though there was no express assignment of the right. ${ }^{104}$ By using the notice concept, the law passes over the lack of direct assent. It can move the benefits and burdens of land allocation agreements to future generations, thus preserving these efficient arrangements.

This leads to the second major distinctive feature of real estate agreements-potentially high transactions costs. In traditional bilateral contracts, the two parties are easily identifiable and can find each other to negotiate changes in the contract. When real property arrangements are transferred to future owners, there is a strong possibility that it may be difficult to find and negotiate with the new stakeholder, especially if the number of interested parties multiplies over the generations. For example, covenants in gross, where the person benefited by the covenant does not own neighboring land benefited by the covenant, were traditionally deemed unenforceable, perhaps out of a fear that it would be difficult to track down successor owners of the benefit if that right were assigned. ${ }^{105}$ A large number of tenants in common can create difficulties in locating and negotiating amendments to address problems that have developed with the original agreement. ${ }^{106}$ With future generation involvement, traditional contract theory and solutions may be problematic.

\section{Liberty}

Through the making of land allocation agreements, people exercise their freedom of choice and control over their own property. They can decide what will give them personal satisfaction-whether

104. Gerald Korngold, Private land Use ArRangements: Easements, Real COVENANTS, AND EQUITABLE SERVITUDES $\$ 8.01$ (2004) [hereinafter KorNGOLD, Private Land Use ARRANGEments]. See, e.g., City of Oceanside v. McKenna, 264 Cal. Rptr. 275, 280 (Ct. App. 4th 1989) ("At the very least, McKenna had constructive notice of the restriction ....").

105. See Korngold, PRIVATE Land USe ARRANgements, supra note $104, \S 9.15$. The Third Restatement permits such interests, RESTATEMENT (THIRD) OF PROP. $\$ \S 4.5,4.6$ (2000), and deals with potential problems through a modification doctrine. Id. $\$ 7.13$. For a related issue of standardization of interests, see Henry Hansmann \& Reinier Kraakman, Property, Contract, and Verification: The Numerus Clausus Problem and the Divisibility of Rights, 31 J. LEGAL STUD. 373, 379-80 (2002) (stating that standardization of property rights allows potential purchasers to more efficiently determine which rights they are considering acquiring); Thomas Merrill \& Henry Smith, Optimal Standardization in the Law of Property: The Numerus Clausus Principle, 110 YALE L.J. 1, 3-4 (2000) (examining the proposition that property law only recognizes interests that conform to a finite number of well-defined forms).

106. See Thomas Mitchell, From Reconstruction to Deconstruction: Undermining Black Landownership, Political Independence, and Community Through Partition Sales of Tenancies in Common, 95 Nw. U. L. REv. 505, 518 (2001) (explaining that conflicting personal interests among common owners become more prevalent as land passes down through generations). 
or not others or efficiency rules would agree. Future purchasers with notice "buy into" those expressions of liberty, and these choices are deemed to be theirs as well.

In the absence of an overriding public policy consideration, ${ }^{107}$ these individual choices should be respected. ${ }^{108}$ For example, ownersinitial or subsequent buyers with notice-choosing to live in a planned community with shared common areas and a scheme of restrictive covenants (perhaps creating limitations on architectural design, use of the properties, parking, and the like) have determined that this will make them happy. In exchange for giving up some power to the community, the individual owner receives enhanced "health, happiness, and peace of mind." ${ }^{109}$ While not everyone might make that choice, everyone should have the option to decide for himself or herself. The individual is best suited to make the determination as to what will make him or her happy, and the law should not intrude or trump that choice except in the rarest of cases.

Respecting the preference of the individual land owner has particular resonance in light of the centrality of land acquisition in the hopes and aspirations of individual immigrants to the United States and the social and political importance of ownership. ${ }^{110}$ As one judge observed, "those individuals who have invested their life savings in ... a home, 'The American Dream,' are entitled to protection under the law, including enforcement of the covenant, which they relied on when investing in the area ...." Freedom of choice with respect to one's own property is a central principle that should benefit both present and future actors.

107. See Korngold, Private Land Use Arrangements, supra note 104, $\$ 10.2$ (addressing issues associated with covenants violating public policy).

108. See ELY, supra note 15, at 17 (emphasizing that the protection of private property is integral to prevent arbitrary government interference); Richard A. Epstein, Notice and Freedom of Contract in the Law of Servitudes, 55 S. CAL. L. REv. 1353, 1359-60 (1982) (arguing that covenants should be enforced to protect private property interests and freedom of contract and that efficient land use and freedom of alienation are not sufficient justifications for non-enforcement); John Leland Mechem, The Peasant in His Cottage: Some Comments on the Relative Hardship Doctrine in Equity, 28 S. CAL. L. REv. 139, 144 (1955) ("[T] he doctrine persists, not because the plaintiff is a cottager or poor, but because of the underlying, the basic concept, that private ownership of a dwelling house is still the most inviolable of all property rights."); Uriel Reichman, Judicial Supervision of Servitudes, 7 J. LEGAL STUD. 139, 158 (1978) ("Private planning is the domain of individual decision making."); see also Loeb v. Watkins, 240 A.2d 513, 516 (Pa. 1968) ("Where a man's land is concerned, he may impose ... any restriction he pleases.").

109. Hidden Harbour Estates, Inc. v. Norman, 309 So. 2d 180, 182 (Fla. Dist. Ct. App. 1975).

110. See supra Section I (discussing the development of American land ownership and property law).

111. Crowley v. Knapp, 288 N.W.2d 815, 828 (Wis. 1980) (Coffey, J., dissenting). 


\section{B. Free Alienability}

Although the policy of freedom of contract would argue for the enforcement of all consensual land allocation agreements, another major policy-free alienability of real property-may require the abrogation of some land contracts. This historical preference for free alienability is variously referred to by the courts as a policy against restraints on alienation ${ }^{112}$ or a policy of free and unrestricted use of land. ${ }^{113} \quad$ This policy is often specifically articulated by courts adjudicating cases concerning real covenants and equitable servitudes, ${ }^{114}$ possibilities of reverter, ${ }^{115}$ or rights of entry ${ }^{116}$ that attempt to limit the transfer of the property ${ }^{117}$ or impose obligations that might decrease marketability (such as use restrictions, requirements to develop the property, or obligations to pay dues). ${ }^{118}$

112. See, e.g., City of Oceanside v. McKenna, 264 Cal. Rptr. 275, 279 (Ct. App. 1989) (balancing the reason for the use restriction against the level of restrictiveness to determine whether restraint is reasonable); Mountain Springs Ass'n v. Wilson, 196 A.2d 270, 276 (N.J. Super. Ct. Ch. Div. 1963) (following the first Restatement of Property to invalidate unreasonable restraint on alienation); Eagle Enter., Inc. v. Gross, 349 N.E.2d 816, 819-20 (N.Y. 1976) (condemning enforcement of an affirmative covenant as an unreasonable restraint on alienation); Gregory v. State Dep't of Mental Health, Retardation \& Hosps., 495 A.2d 997, 1000, 1002 (R.I. 1985) (interpreting a covenant to favor free alienability and allowing group home).

113. See, e.g., Mountain Home Props. v. Pine Mountain Lake Ass'n, 185 Cal. Rptr. 623, 628 (Ct. App. 1982) (applying the general rule that when a covenant's enforceability is at issue, it will be resolved in favor of free use of the land); Waikiki Malia Hotel, Inc. v. Kinkai Prop. Ltd. P'ship, 862 P.2d 1048, 1057 (Haw. 1993) (stating that restrictive covenants will be construed in favor of grantee and against grantor); see also Kitching v. Brown, 73 N.E. 241, 246 (N.Y. 1905) (favoring unrestricted land use by interpreting a covenant that restricted the erection of "tenement houses" as not prohibiting "apartment houses").

114. See, e.g., Amana Soc'y v. Colony Inn, Inc., 315 N.W.2d 101 (Iowa 1982); Spanish Oaks, Inc. v. Hy-Vee, Inc., 655 N.W.2d 390, 395 (Neb. 2003); Ragland v. Overton, 44 S.W.2d 768, 769 (Tex. Civ. App. 1931); Crozuley, 288 N.W.2d at 816.

115. See, e.g., Alby v. Banc One Fin., 82 P.3d 675, 677 (Wash. Ct. App. 2003) (holding that a fee simple determinable subject to automatic reverter is not a prohibited restraint on alienation).

116. See, e.g., Carma Developers (Cal.), Inc. v. Marathon Dev. Cal., Inc., 826 P.2d 710, 712 (Cal. 1992); City of Lincoln v. Townhouser, Inc., 534 N.W.2d 756, 757 (Neb. 1995).

117. See, e.g., Carma Developers, 826 P.2d at 712 (right of entry on leasing); City of Oceanside, 264 Cal. Rptr. at 276-77 (covenant barring leasing and requiring owner occupancy); Floyd v. Hoover, 234 S.E.2d 89, 91 (Ga. Ct. App. 1977) (right of entry creating repurchase option).

118. See, e.g., Falls City v. Mo. Pac. R.R., 453 F.2d 771, 772 (8th Cir. 1971) (condition requiring the construction of improvements); Neponsit Prop. Owners' Ass'n v. Emigrant Indus. Sav. Bank, 15 N.E.2d 793, 797 (N.Y. 1938) (original deed requiring dues payments to association); Anderson v. Bommer, 926 P.2d 959, 961 (Wyo. 1996) (covenant limiting type of structures); see also RESTATEMENT (THIRD) OF PROP. $\$ 3.4$ (2000) (invalidating unreasonable restraints on alienation); KORNGOLD, PRIVATE LAND USE ARRANGEMENTS, supra note 104, $\$ \$ 9.16,10.03$ (discussing, respectively, that a notice system increases marketability and that zoning may restrict land use and limit enforceability of covenants); Gerald Korngold, For Unifying Servitudes and Defeasible Fees: Property Law's Functional Equivalents, 66 TEx. L. REv. 533, 
Free alienability also represents a broader concern that seeks to make land more attractive in the marketplace and may even support affirmative legal doctrines to accomplish that goal. ${ }^{119}$

Most often the courts do not explain the theory behind the free alienability doctrine or sometimes state circularly that restraints on alienation are "repugnant" to the fee. ${ }^{120}$ Free alienability can be understood as a policy to promote the market economy and limit dead hand control. These goals are of great importance to future generations. Courts and legislatures must ensure that legal doctrines and activities of current owners do not unduly interfere with those values.

\section{Promoting a market economy}

The policy of free alienability is a means to unleash market forces to act on property and to encourage the economic development of our limited land resources. ${ }^{121}$ Direct restraints on alienation, such as a provision barring the sale of property, freeze a parcel out of the market place and prevent it from being devoted to the uses by those who value it the most. ${ }^{122}$ This can lead to the loss of the important efficiency benefits of market transactions in land. Anglo-American

$542-43$ (1988) (explaining that defeasible fees and real covenants may result in decreased marketability). This Article's discussion focuses on transfers for consideration that contain such restrictions. There is a large body of law dealing with gratuitous transfers (by will, trust, or deed) containing various land restrictions as well as rules on the donee's personal behavior. See RESTATEMENT (SECOND) OF PROP. $\$ \S 3.1-8.3$ (defining various restraints and discussing their validity). Since there is no consideration and mutual bargaining in those situations, they are of some, but not binding, relevance to the problem discussed here.

119. See, e.g., the doctrine of relocation of easements, discussed in Section IV.C.1. Similarly, the doctrine of easements by necessity, where the court draws in an access way for a landlocked parcel after subdivision, is designed to permit reasonable exploitation of the property, so that a future buyer would be willing to acquire it. KORNGOLD, PRIVATE LAND USE ARRANGEMENTS, supra note 104, $\S 3.11$. Courts have been so concerned about freedom of contract that they have traditionally justified their action by presuming that the parties intended such a result. Id. $\$ 3.09(\mathrm{c})$. Finally, the unilateral right to partition of joint tenants and tenants in common allows for the physical division or sale of jointly held land by one owner over the other's objection. Delfino v. Vealencis, 436 A.2d 27, 32-33 (Conn. 1980). Otherwise, land could be permanently locked out of the market.

120. See, e.g., Carma Developers, 826 P.2d at 712 (holding that a right of entry in a commercial lease, which allowed the lessor to terminate and recapture the property, was not an unreasonable restraint on alienation); Davis v. Geyer, 9 So. 2d 727 (Fla. 1942) (invalidating a restriction prohibiting the current landowner from selling property without the original owner's approval); Floyd, 234 S.E.2d at 93 (determining that a condition subsequent reserving the right to repurchase was not repugnant to the estate granted).

121. See Iglehart v. Phillips, 383 So. 2d 610, 613 (Fla. 1980) (“marketability”); Drayson v. Wolff, 661 N.E.2d 486, 491 (Ill. App. Ct. 1996) ("power of alienation of real property is socially and economically desirable").

122. See supra Section III.A.l (proffering market benefits of consensual contracts). 
land law has long been concerned about doctrines and practices that render land less attractive to buyers.

Making land marketable and developable has been the key imperative in the evolution of land law, from its initial incarnation in England after the Norman Conquest in the eleventh century through the time of the reception of much of the English common law into the early American legal system and continuing to the current day. ${ }^{123}$ Changes in the English law over the centuries transformed land from a means of assuring the monarch of loyalty from feudal lords into a commercial asset, a commodity, that could be bought and sold in the marketplace. A few of the important stops along the way were the Statute Quia Emptores, allowing for inter vivos transfers of land; ${ }^{124}$ the abolition in England and then later in the United States of the fee tail, which previously had exemplified a link between land ownership and blood ties, so that land could pass unfettered to unrelated buyers; ${ }^{125}$ and the validation of paper conveyances of realty, rather than the personal and direct process of livery of seisin, allowing land to be bought and sold from a distance in a commercial market. ${ }^{126}$

Often the policy of free alienability exists symbiotically with notions of freedom of contract. As long as free alienability is deployed to dispatch archaic doctrines that slow market transactions-such as the rule requiring livery of seisin to convey property or the feudal rules barring inter vivos transfer of land-then alienability serves to permit transactions that contract theory endorses and celebrates. At times, though, there is a major conflict. For example, when parties voluntarily agree to a fee tail transfer and the law trumps that agreement, contract values fall to alienability goals.

Deciding the winners and losers in these clashes is difficult but most important to future generations who must live in a world of perpetual land ties. Given the commoditized view of land in American history, the free alienability doctrine has particular resonance and application. Free alienability concerns can also be understood as a vehicle to preserve for future generations the benefits of the market economy and freedom of contract found so

123. Friedman, supra note 18 , at 177 ; see Jesse Dukeminier ET AL., Property 181 (6th ed. 2006) (describing the influence of demand for land on transferability of land after Norman Conquest).

124. CASNER ET AL., supra note 100 , at 308-09.

125. See MOYNIHAN \& KuRTz, supra note 71, at 52-55 (suggesting that American opposition to fee tail arose out of association of the fee tail with primogeniture and also with its use to maintain concentration of land ownership in England).

126. See 1 AMERICAN LAW OF Property $§ 1.31$ (A. James Casner ed., 1952) ("[The Statute of Enrollments] provided that every bargain and sale of a free-hold interest should be made by an instrument ...."). 
useful by current owners. Thus, free alienability doctrines can be used to void land use arrangements that will unnecessarily and unjustifiably harm future market exchanges. The law provides that a direct restraint on alienation will be invalidated if it is unreasonable, based on the balancing of the utility of the restriction against the negative effect of enforcement on the parties and other compelling policies. ${ }^{127}$ Interestingly, there appears to be a pattern in recent cases of holding an original contracting party to the agreement in spite of free alienability concerns, ${ }^{128}$ perhaps giving a nod toward contract considerations. At the same time, though, the courts are striking restrictions where enforcement is sought against a successor, ${ }^{129}$ perhaps recognizing the future generations issue.

Restrictions in real covenants, such as building and use controls, may also have the indirect effect of discouraging buyers and reducing the value and potential development of the property. ${ }^{130}$ Because such covenants are manifestations of the parties' freedom of contract, with the benefits that this brings, the law should generally enforce such agreements. The effect on marketability would only be limited because a prospective buyer would adjust the offer price downward to reflect the loss in value due to the restriction. Presumably, the price for land subject to a covenant would be lower than that for

127. See Gale v. York Ctr. Cmty. Coop., Inc., 171 N.E.2d 30, 33 (Ill. 1960) (“[A] restraint may be sustained ... when it is reasonably designed to attain or encourage accepted social or economic ends."); RESTATEMENT (THIRD) OF PROP. $\$ 3.4(2000)$. See, e.g., Carma Developers (Cal.), Inc. v. Marathon Dev. Cal., Inc., 826 P.2d 710, 712, 718 (Cal. 1992) (upholding a clause terminating a lease pursuant to a recapture clause if tenant sought to assign or sublease because the court found it was a validly negotiated business term, only a leasehold was involved, and the effect on alienation was, therefore, by definition limited); City of Oceanside v. McKenna, 264 Cal. Rptr. 275, 280-81 (Ct. App. 1989) (enforcing a covenant barring leasing and requiring owner occupancy in subsidized housing in light of the limited duration of the covenant and public policy favoring affordable housing); Camino Gardens Ass'n, Inc. v. McKim, 612 So. 2d 636, 64142 (Fla. Dist. App. 1993) (affirming the lower court's judgment that a clause giving a homeowners' association the right to purchase defaulted properties at fixed price tied to outstanding sums due on the mortgage was an unreasonable restraint and would discourage lending); Alby v. Banc One Fin., 82 P.3d 675, 676-78, 680 (Wash. Ct. App. 2003) (allowing reverter barring encumbrance of property, where the time of the prohibition was limited to the lifetime of the grantor, who had legitimate purpose in limiting encumbrances and the bargain sale transaction at issue was within a family and clearly understood).

128. See, e.g., City of Oceanside, 264 Cal. Rptr. at 725; Carma Developers, 826 P.2d at $710 ;$ Alby, 82 P.3d at 675.

129. See, e.g., Camino Gardens Ass'n, Inc., 612 So. 2d at 638 (denying enforcement against a mortgagee who accepted a deed in lieu of foreclosure and against the purchaser from the mortgagee).

130. See Korngold, Private Land USE ARRAngements, supra note 104, at 299 (highlighting the potential for covenants to elevate transaction costs that interfere with marketability of covenanted property, despite a potential buyer's ability to take the covenant into account and adjust the price accordingly). 
unencumbered property. Where a buyer seeks to enjoy the property free and clear of an existing covenant, the buyer could negotiate a release from the covenant holder. Thus, as a general matter, land can pass in the marketplace despite the presence of covenants, although wholly irrational covenants may present problems to virtually all buyers. ${ }^{131}$

There are rare situations where alienability concerns will trump contract norms. A few examples are discussed below-relocation of easements, obsolete agreements, and conservation easements. Future generations require such intervention.

\section{Dead hand control}

The policy of free alienability serves another key societal goal by limiting the control of past owners over future generations. Such dead hand control can be harmful when it blocks current owners from altering the use of their property or transferring or encumbering their property in response to market demands. ${ }^{132}$ This may result in a poor utilization of our limited land resources. As developed above, land allocation agreements are quite different from run-of-the-mill contracts since the subject matter, and thus the agreement, can be perpetual. The current, most efficient use of land is hard enough to determine; trying to predict how land should best be used by future generations requires a good measure of hubris. Current actors and decision-makers should not unduly interfere with the market exchanges of future owners.

An unlimited reach of past land use allocation arrangements can also have a negative impact on the aspirations and autonomy of future owners. First, enforcement of direct restraints on transfer of property harms individuals-it forces people to continue to live in places where they no longer want to stay and prevents people from being able to move into properties that they could afford and want to occupy. ${ }^{13}$

131. Restatement (Third) OF Prop. $\$ 3.5(2) \mathrm{cmt}$. b (2000). This provision is in a sense a substitute for the traditional touch and concern requirement which, inartfully, served to void irrational covenants. See KoRnGOLD, Owners Associations, supra note 57, at 523-26 (arguing that land use restrictions may prevent current owners from adapting land use to current needs and limit land use of future generations, but that some subdivision restrictions measurable by objective criteria and relating to external behaviors should be nevertheless enforced).

132. See, e.g., In re Turners Crossroad Dev. Co., 277 N.W.2d 364, 368 (Minn. 1979) ("This court has serious reservations about the wisdom of allowing provisions contained in a 1949 real estate transaction ... to prevent the development of a substantial piece of real estate in 1978.").

133. See ReSTATEMENT (THIRD) OF PROP. \$ $3.4 \mathrm{cmt}$. c (2000) (discussing restraints on alienation). 
Moreover, various covenant arrangements control activities, choices, and behavior within individual homes, such as requiring occupancy by a traditional family ${ }^{134}$ or effectively prohibiting group homes for the disabled. ${ }^{135}$ As developed above, ownership of land has played a major role in the American experience, providing owners with a source of pride, social status, and economic power. The family home is a place of self-actualization. Land use allocation arrangements that interfere with the ability to do what one wishes within one's home threaten key values. Moreover, it is perilous to predict social values of the future and attempt to impose them on owners down the line. Our history of covenants barring occupancy of land by racial minorities and Jews should remind us that the past's concept of an ideal society can be reprehensible to future generations. $^{136}$ This experience should give us a good measure of humility about our attempts to impose our judgments on owners to come. Section IV.D.1 will show how subdivision covenants might occasionally fail to protect personal autonomy from the dead hand.

The imperfect, sometimes maddening Rule Against Perpetuities does have the salutary effect of teaching about the societal dangers of allowing past owners to interfere with current owners. The Rule has been highly relevant in donative transfers. It rarely makes an appearance with land agreements and transfers for consideration, only being applied occasionally with respect to options. ${ }^{137}$ Moreover, over the past couple of decades, approximately half of the American jurisdictions have abolished the Rule as applied to truststraditionally the main focus of the Rule. ${ }^{138}$ Legislatures have

134. See Korngold, Single Family, supra note 50, at 951-70 (describing the enforcement of servitudes requiring occupancy by a "traditional" family).

135. See, e.g., Adult Group Props., Ltd. v. Imler, 505 N.E.2d 459, $462-63$ (Ind. Ct. App. 1987) (enforcing the trial court's interpretation of a covenant restricting use to single family dwellings as prohibiting the construction of group home for developmentally disabled); Omega Corp. v. Malloy, 319 S.E.2d 728, 729, 732 (Va. 1984) (declining to interpret a zoning ordinance as allowing construction of a home for mentally disabled where the covenant restricted use to residential purposes and single family dwellings). But see Maull v. Cmty. Living for the Handicapped, Inc., 813 S.W.2d 90, 91-92 (Mo. Ct. App. 1991) (allowing construction of a home for mentally disabled, despite a covenant restricting use to "one family," where the building would have the appearance of single family dwelling).

136. See infra Section IV.D.1 (evaluating the application of covenants and easements in subdivisions).

137. See, e.g., St. Regis Paper Co. v. Brown, 276 S.E.2d 24, 26 (Ga. 1981) (refusing to apply the Rule to an option in a lease); Pace v. Culpepper, 347 So. 2d 1313, 1316 17 (Miss. 1977) (applying the Rule to void an option); Coulter \& Smith, Ltd. v. Russell, 966 P.2d 852, 857-59 (Utah 1998) (concluding that contract construction rules should apply to commercial option before the Rule).

138. Max M. Schanzenbach \& Robert H. Sitkoff, Perpetuities or Taxes? Explaining the Rise of the Perpetual Trust, 27 CARDOZO L. REv. 2465, 2466-67 (2006); Robert H. Sitkoff 
abrogated the Rule not because of its underlying policy but to take advantage of federal tax benefits confirmed by the Tax Reform Act of $1986 .{ }^{139}$ The passing of the Rule is at great cost if we forget its important warning about balancing the control of past generations against the wishes of the present owners.

\section{ACCOMmOdATING CONTRACT AND ALIENABILITY FOR FUTURE GENERATIONS}

There can be no unitary accommodation of the contract and alienability values. Often, there will be no conflict between these two principles. If and when they are in conflict, a particular court or legislature acting as a decision-maker will rely on specific facts, circumstances, and policy concerns to make a determination that accommodates these two principles. Still, some overall observations can be made to guide decision-makers and legal actors with respect to future generations.

First, legal rules and the land transactions and recording systems need to provide the benefits of market transactions not only for current owners but also for future generations and proximate successors. Freedom of contract-and the ability to achieve happiness through consensual arrangements-for future owners cannot be compromised by system rules that unfairly favor current owners over successors. Rules of interpretation, enforcement, and recording system architecture must permit the achievement of contract benefits in the future as well as the present. By addressing these issues, courts and legislatures will help to bring great opportunities to future generations.

Second, the current generation has to accept that land agreements of today will often affect the future and that the future is fundamentally indeterminate. Efforts by parties to provide for the future have proven tricky at times. Consider, for example, the issue of re-setting rents in long-term leases. The case law is littered with failed attempts to find a workable formula that would account for even a few prosaic changes in facts on the ground. ${ }^{140}$ This does not

\& Max M. Schanzenbach, Jurisdictional Competition for Trust Funds: An Empirical Analysis of Perpetuities and Taxes, 115 YALE L.J. 356, 373-76 (2005) [hereinafter Trust Funds].

139. Sitkoff \& Schanzenbach, Trust Funds, supra note 138, at 359 ("The driving force behind the erosion of the Rule was not a careful reconsideration of the ancient common law policy against perpetuities, but rather a 1986 reform to the federal tax code.").

140. See Milton R. Friedman, Friedman ON Leases $\$ \$$ 5:4-5:4.6 (Patrick A. Randolph Jr. ed., 5th ed. 2005) (comparing and contrasting issues associated with agreements that provide for, through the use of various formulas, future 
give great confidence about our ability to address highly complex conditions that are by definition beyond our contemplation. We would be wise to maintain some humility about our ability to use current market transactions to solve everything today for the future. Future generations deserve the opportunity to find the solutions to the problems of their day, and they most likely will have greater success than people long gone from the scene.

Despite these significant caveats, because of the great benefits brought to individuals and the collective through market transactions, ${ }^{141}$ the value of freedom of contract should be respected as a general matter and land allocation agreements generally enforced as a matter of course. These arrangements brought efficiency and liberty benefits to the original parties and likely continue to benefit future generation owners who are deemed to have assented to them by taking with notice. Moreover, if the future generation owners wish to alter or annul the agreement, they can (except in the unusual case) bargain with each other to do so, with the resulting benefits of a market transaction.

In rare situations, however, a court or legislature may find that free alienability considerations about future generations require the nonenforcement of an agreement, the limitation of remedies to monetary damages (as opposed to injunctive relief), ${ }^{142}$ or other appropriate action (such as a legislative eminent domain proceeding). ${ }^{143}$ These situations are most likely to arise when a past land allocation agreement substantially interferes with the personal autonomy of a future owner or stands in the way of the public's ability to deal with a major future challenge. Judicial refusal to enforce on alienability grounds would fit within the longstanding principle

determination of increases in rent or tax payments). For example, there is often a conflict as to whether property reappraisal should consider the leasehold as an encumbrance: Compare Eltinge \& Graziadio Dev. Co. v. Childs, 122 Cal. Rptr. 369, 372 (Ct. App. 2d 1975) (determining that an appraisal should be based on market value and not account for property's use as shopping center), with Plaza Hotel Assocs. v. Wellinton Assocs., 285 N.Y.S.2d 941, 946 (N.Y. App. Div. 1967) (holding that a lease limited appraisal of property to the value as restricted by lease), aff $d, 28$ A.D.2d 1209 (N.Y. App. Div. 1967), aff'd, 239 N.E.2d 736 (N.Y. 1968).

141. See supra Section III.A (introducing freedom of contract and free alienation as important themes in American property law).

142. See Boomer v. Atl. Cement Co., Inc., 257 N.E.2d 870, 877 (N.Y. 1970) (refusing an injunction for nuisance because of public interest in operation of cement plant); Restatement (THIRD) OF ProP. $\$ 8.3 \mathrm{cmt}$. h (2000) (outlining the remedies available when determining whether to enforce servitudes and explaining how costs and benefits of enforcement may be considered when electing appropriate relief); KORNGOLD, PRIVATE LAND USE ARRANGEMENTS, supra note $104, \$ 11.08$ (detailing various approaches to applying the doctrine of relative hardship to determine whether an injunction should be issued to enforce a covenant).

143. See infra Section IV.E (arguing in favor of a broad definition of public use). 
barring enforcement of agreements violating public policy, here paying special attention to negative effects on future generations. ${ }^{144}$

These broad guidelines are illustrated by five scenarios chosen from the spectrum of real property law. Scenarios 1 and 2 indicate how aspects of current doctrine and architecture of the recording system unduly favor current owners over subsequent owners, both future generations as well as proximate successors. Scenarios 3, 4, and 5 demonstrate the need to preserve flexibility for future generations and show various private and public law vehicles that could do so. This discussion will show that existing legal rules and doctrines generally and unreasonably favor current owners over future generations, resulting in poor utilization of our limited land, inefficient real estate markets, and undue burdens on personal autonomy. ${ }^{145}$ These failures will be contrasted with those rarer situations where courts and legislatures get it right.

Scenario 1: Unclear Undertakings by First Generation Parties

Scenario 2: System Architecture and Operation

Scenario 3: Things Change

Scenario 4: Poor Predictions by Private Parties

Scenario 5: The End of the Eminent Domain Trump Card?

\section{A. Scenario 1: Unclear Undertakings by First Generation Parties}

Land allocation agreements may contain ambiguities that affect not only the original contracting parties but also future owners. These conflicts might ensnare successors who purchased soon after the original transfer or quite far into the future. In developing rules to give meaning to these terms, courts and legislatures need to carefully consider successor owners. By doing so, they will help to achieve fair treatment of future generations.

Sometimes the original parties to land allocation agreements are unclear as to the intended terms of the deal. The parties may have failed to clarify in the document ${ }^{146}$ the nature and extent of the

144. See Restatement (ThIRD) OF PROP. $\$ 3.1$ (favoring the presumption that servitudes are valid unless they violate public policy).

145. It is hard to find situations where successor generations are given advantages over original parties. One example is the holder-in-due-course doctrine that permits an assignee of a mortgage note to require the mortgagor to pay the assignee even though (a) the mortgagor has already paid the original mortgagee (the assignor), and (b) the assignee did not notify the mortgagor that it had taken assignment of the note. KORNGOLD \& GOLDSTEIN, supra note 102, at 431-44.

146. The document would most likely be a deed. While a deed is technically a unilateral conveyance, the process of delivery and acceptance can be seen as an agreement. 
property interest that was conveyed, ${ }^{147}$ the existence and scope of an easement, ${ }^{148}$ the legal description of the parcel being conveyed, ${ }^{149}$ activities prohibited by a restrictive covenant, ${ }^{150}$ or a host of other issues. With general (i.e., non-land) contracts there are similar misunderstandings. Courts have used a variety of approaches to find the true intent of the contracting parties in general contracts. Some courts prefer to hew closely to the language of the document, sometimes described as a "plain meaning rule," believing that nothing better expresses the intent of the parties than the words that they chose. ${ }^{151}$ Other courts, however, are more willing to consider extrinsic evidence to get to the true intent of the promisor and promisee, recognizing the imprecision of language and the importance of other evidence. ${ }^{152}$ This divergence has provoked some significant debate in the literature, with the former outlook sometimes referred to as the "objective" view and the latter as the "subjective" approach. ${ }^{153}$

147. See, e.g., Guido v. Baldwin, 360 N.E.2d 842, 845 (Ind. Ct. App. 1977) (resolving ambiguity in eighty-acre conveyance that reserved "the small cottage and a half acre garden plot”); Stone v. U.S.D. No. 222, 91 P.3d 1194, 1196 (Kan. 2004) (concluding that conveyance unambiguously conveyed property in fee simple, not with an easement); Barber v. Flynn, 628 P.2d 1151, 1154-55 (Okla. 1980) (per curiam) (emphasizing the importance of parties' intent when interpreting an instrument of conveyance and recognizing the retention of mineral rights by the grantor).

148. See, e.g., N. Utils., Inc. v. City of S. Portland, 536 A.2d 1116, 1118 (Me. 1988) (determining that a utility company's easement prevented construction of sidewalk); Mitchell v. Chance, 149 S.W.3d 40, 45-46 (Tenn. Ct. App. 2004) (allowing an easement where the deed referred to a road as right of way).

149. See, e.g., Fin. Inv. Corp. v. Tukabatchee Area Council, Inc., 353 So. 2d 1389, 1391 (Ala. 1977) (reversing the trial court finding that the language describing the property was ambiguous); Stevens v. Wilson, 408 N.E.2d 496, 500 (Ill. App. Ct. 1980) (permitting consideration of extrinsic evidence to determine which property was subject to the parties' contract); Flanagan v. Prudhomme, 644 A.2d 51, 58-61 (N.H. 1994) (considering the location and scope of right of way after a survey indicated that the right of way was incorrectly located).

150. See, e.g., Hines v. Heisler, 439 So. 2d 4, 5-6 (Ala. 1983) (refusing to allow construction of multifamily townhouses where a covenant restricted use to "private" residential uses); Cottrell v. Miskove, 605 So. 2d 572, 573-74 (Fla. Dist. Ct. App. 1992) (interpreting a covenant as prohibiting defendants from parking a pickup truck, used for small business, outside the garage).

151. See, e.g., Beanstalk Group v. AM Gen. Corp., 283 F.3d 856, 859 (7th Cir. 2002) (acknowledging that contracts should usually be enforced based on the ordinary meaning of words without resort to extrinsic evidence).

152. See, e.g., Pac. Gas \& Elec. Co. v. G.W. Thomas Drayage \& Rigging Co., 442 P.2d 641, 644 (Cal. 1968) (“ $[\mathrm{T}]$ he exclusion of relevant, extrinsic evidence to explain the meaning of a written instrument could be justified only if it were feasible to determine the meaning the parties gave to the words from the instrument alone."); RESTATEMENT (SECOND) OF CONTRACTS § $212 \mathrm{cmt}$. b (1981) (allowing extrinsic evidence to determine if language is ambiguous in the first place).

153. E. Allan Farnsworth, William F. Young \& Carol Sanger, Cases and MATERIALS ON CONTRACTS 119-20, 580-85 (6th ed. 2001). See generally Robert Braucher, Interpretation and Legal Effect in the Second Restatement of Contracts, 81 Colum. 
Whatever one's position on the issue of the interpretation and construction of general contracts, when it comes to enforcement of land allocation agreements with a successor involved, it is essential to take a "strict construction" or "objective" approach. This view, favoring the language of the document and questioning the use of extrinsic evidence, will provide fair protection to future generation actors. As developed above, ${ }^{154}$ successor owners bound by agreements (such as easements, covenants, and even mortgages) become obligated without direct assent through a type of legal fiction: by purchasing with notice of the agreement, the successor is deemed to have consented to fulfill its terms. The time at which the successor buys is the actual moment of assent. Thus, courts construing an unclear land allocation agreement should focus on the successor's reasonable understanding of the meaning of the original agreement based on the language and circumstances available to the successor at the time of his or her purchase. In the absence of such an approach, the market will be skewed for future generations and they may hesitate to invest in transactions since there may be hidden traps. Moreover, the personal autonomy of successor owners will be severely offended if they are bound by undiscoverable choices of past generations. Both freedom of contract and free alienability considerations support the suggested method of interpreting language of land allocation agreements when a successor owner is involved.

In interpreting land allocation agreements concerning successors, courts should therefore protect the legitimate needs of subsequent buyers on two levels. First, courts should, whenever possible, decide cases relying exclusively on the express language of the parties in the document. They should be highly reluctant to allow extrinsic evidence. This will cut down on the need for a successor to make the difficult inquiry beyond the recorded document in order to determine what the document means, or worse, could mean.

Second, when the courts are forced to admit extrinsic evidence because they can in no way find the parties' understanding from the document alone, they must be vigilant in protecting the interests of successor owners. Although conversations and other documents between the original parties may be admissible (and highly relevant)

L. REV. 13 (1981) (noting the revision's added emphasis on parties' intent and context of agreement); David Charny, Hypothetical Bargains: The Normative Structure of Contract Interpretation, 89 MICH. L. REV. 1815 (1991) (addressing difficulties associated with the use of hypothetical bargain when interpreting contracts).

154. Supra Section III.A.1.b. 
to interpret the land allocation agreement in an action between those two parties, that evidence should not be admissible in an action between the successor and the remaining original party unless the successor had actual, record, or inquiry notice of such matters before buying. Similarly, any other evidence extant at the time of the original agreement or subsequently developing should only be admissible if the later buyer had "notice" of the evidence at the time she took her interest. To the extent that a strict construction approach might lead to a somewhat imperfect rendition of the true intent of the original contracting parties, that loss is acceptable in order to protect a successor who has entered into the story line. The original parties could have protected themselves with careful drafting.

Given this need to protect the legitimate expectations of future owners, it is troubling to see courts in land agreement cases resorting to the statements of general contracts cases, perhaps without thinking or just getting it wrong. Many courts simply declare that parol evidence is admissible to ascertain the true meaning of the land allocation agreement, ${ }^{155}$ as if it were a simple dispute between the original contracting parties. ${ }^{156}$ Some unfortunately go further to make express, and shocking, statements such as, "[d]eeds are construed according to ordinary rules of contract construction."157 Moreover, these courts look to extrinsic evidence in existence at the time of the original transaction, without considering whether it would be known to a subsequent buyer. ${ }^{158}$ In a case involving successors to both the grantor and grantee of contested mineral rights, an appellate court stated that the lower court "properly placed itself in the position of the parties to the conveyance when the instrument was executed, and considered, by the admission of parol evidence, the surrounding circumstances in order to ascertain the intent of the parties." 159 Another, dealing with a successor, intoned that "we

155. See, e.g., Greenan v. Lobban, 717 A.2d 989, 991 (N.H. 1998); Barber v. Flynn, 628 P.2d 1151, 1154 (Okla. 1981); Main St. Landing, L.L.C. v. Lake St. Ass'n, 892 A.2d 931, 935 (Vt. 2006).

156. Where the dispute remains between the original parties to the agreement, taking a generous approach to extrinsic evidence does not interfere with successors' expectations. For such a dispute, see Graessle v. State Highway Comm'n, 784 S.W.2d 213, 214 (Mo. Ct. App. 1989).

157. Capital Assets Fin. Servs. v. Lindsay, 956 P.2d 1090, 1093 (Utah Ct. App. 1998).

158. See, e.g., Hooks v. Spies, 583 S.W.2d 569, 571-72 (Mo. Ct. App. 1979); Arbogast v. Pilot Rock Lumber Co., 336 P.2d 329, 331-32 (Or. 1959); Main St. Landing, 892 A.2d at 935 .

159. Besing v. Valley Coal Co., 293 N.E.2d 510, 513 (Ind. Ct. App. 1973). 
interpret the deed's language in the context of the circumstances under which it was drafted.

Moreover, some actual decisions are also out of step with the special perspective that should be used in deed interpretation involving subsequent owners. One court, for example, had to determine whether a grantor had reserved a separate half-acre garden plot and a cottage from an eighty acre conveyance or whether the grantor intended only to reserve the cottage and the little area upon which it sat. ${ }^{161}$ The defendant was the successor to the grantor and the plaintiffs were successors to the original grantee. ${ }^{162}$ In deciding this 1977 case, the court refused to give weight to evidence that showed that the plaintiffs did not pay taxes on the second halfacre but the defendant did, and instead was interested only in evidence surrounding the 1939 conveyance. ${ }^{163}$ It is curious to ignore the course of dealing that would show what the plaintiffs and defendant (i.e., successor owners) thought the agreement meant, and instead favoring the view of the original grantor regardless of whether this was known to future generations.

Some courts, albeit a few, do adopt statements and make decisions that are more favorable to future generation concerns. They appear to do so, however, simply out of obeisance to a strict constructionist view of contracts between the original promisor and promisee and show no understanding that successor cases might involve special protections. While these declarations may be pleasing and some results correct, these cases are not an adequate response to the issue of future generations and land allocation agreements. Thus, some courts state that they will not apply rules of construction to a land allocation agreement if the language is clear and unambiguous. ${ }^{164}$ They will simply enforce such an agreement according to the plain, ordinary meaning of its language ${ }^{165}$ and extrinsic evidence will be barred. ${ }^{166}$ It is extremely rare for a court to explain why they follow this rule. In the few cases in which they do so, the courts seem to

160. N. Utils., Inc. v. City of S. Portland, 536 A.2d 1116, 1117 (Me. 1988).

161. Guido v. Baldwin, 360 N.E.2d 842, 846 (Ind. Ct. App. 1977).

162. Id. at 845 .

163. Id. at $847-48$.

164. See, e.g., Equitable Trust Co. v. O'Neill, 420 A.2d 1196, 1200 (Del. Super. Ct. 1980); Revelle v. Schultz, 759 P.2d 1255, 1258 (Wyo. 1988).

165. See, e.g., Clark v. Wodehouse, 669 P.2d 170, 173 (Haw. Ct. App. 1983); Gosnay v. Big Sky Owners Ass'n, 666 P.2d 1247, 1250 (Mont. 1983); Mitchell v. Chance, 149 S.W.3d 40, 44-45 (Tenn. Ct. App. 2004).

166. See, e.g., Fin. Inv. Corp. v. Tukabatchee Area Council, Inc., 353 So. 2d 1389, 1391 (Ala. 1977); Stone v. U.S.D. No. 222, 91 P.3d 1194, 1203 (Kan. 2004). 
indicate that it is merely a dispute between the original promisor and promisee and that they must hold the parties to their bargain. ${ }^{167}$

One can scour the case digests to find only the very unusual decision where a court demonstrates an understanding of the issue of the future generations. In a case involving a subdivision with a covenant restricting the parking of certain types of vehicles, the court found that the owners' van was not within the ban, noting that the restriction was unclear. ${ }^{168}$ The opinion insightfully declared that "[p] rospective purchasers of property are ... entitled to know what they will and what they will not be permitted to park on their lots" and " $[\mathrm{n}]$ othing in the language $\ldots$ is calculated to put the reader upon notice." "169

Courts, therefore, should focus on expectations of successor parties when crafting rules of construction of land allocation agreements. Both contract and free alienability notions require as much. Such an emphasis will serve to protect future generations.

\section{B. Scenario 2: System Architecture and Operation}

The land records system and related rules should be designed to create a high-functioning, efficient market. Unfortunately, an analysis of three examples demonstrates that the system has unduly favored current ownership interests, thereby harming the efficiency and integrity of markets for successor owners, both future generation players and proximate successors. Legislative and judicial solutions to these problems will serve to enhance the land transactions market for future generations.

\section{Improper escrow delivery}

A land seller (grantor) may deliver a deed to an escrow agent with instructions for the escrow to deliver the deed to the buyer (grantee) upon the occurrence of certain conditions (often the payment of the price by the grantee). ${ }^{170}$ The following sad story sometimes then occurs: the escrow agent makes an error or is subject to fraudulent action by the grantee and releases the deed to the grantee prior to

167. See, e.g., Tukabatchee, 353 So. $2 \mathrm{~d}$ at 1391 (" $[\mathrm{P}]$ arties must be legally presumed to have intended what is plainly and clearly set out."); Kirven v. Bartell, 223 S.E.2d 597,599 (S.C. 1976) (" $[\mathrm{E}]$ xtrinsic evidence is to be admitted to resolve ambiguities, not create them."); Downer v. Gourlay, 349 A.2d 707, 708 (Vt. 1975) ("[T]he understanding of the parties must be deemed to be that which their own instrument declares.").

168. Lake St. Louis Cmty. Ass'n v. Leidy, 672 S.W.2d 381, 383 (Mo. App. 1984).

169. Id.

170. KORNGOLD \& GOLDSTEIN, supra note 102, at 168-69. 
the fulfillment of the condition. The grantee records the deed and then conveys the land to a bona fide purchaser ("BFP") (i.e., a party paying consideration without notice of the grantor's claim). The issue is who, as between the grantor and the BFP, has the right to title to the property. The loser of this battle will have a right for damages against the grantee and the escrow agent, ${ }^{171}$ and the BFP could recover monetary compensation under a standard title insurance policy if the BFP had purchased a policy, ${ }^{172}$ but the fight is over the title to the land.

Well-established law holds that the grantor prevails over the BFP for title. ${ }^{173}$ In light of the concerns for intergenerational fairness, the general rule is wrong, if not shocking. It can be justified only by the formalistic argument that since the condition has not been fulfilled, the grantor did not meet the intent requirement necessary for a valid delivery. ${ }^{174}$ But that is a clearly inadequate explanation for several reasons. First, there is no way that the BFP could have known of the wrongful act by the escrow; all the BFP would find in the record is a validly executed and recorded deed from the grantor to the grantee. Moreover, the grantor started the chain of events that led to the loss. It was the grantor that voluntarily chose to give the deed to that particular escrow, and so the grantor rather than the BFP should be accountable for the grantor's own act. ${ }^{175}$ Compared to the BFP, the

171. See 11 ThOMPSON ON REAL PROPERTy $\$ 94.06(\mathrm{~g})$ (3) (David A. Thomas ed., 2002).

172. Standard title insurance would grant BFP compensation in this story. See AM. LAND TITLE ASs'N, OWNER'S POLICY OF TITLE INSURANCE $\$$ (2) (a) (iii) (2006), available at http://www.alta.org/forms/download.cfm?formID=155\&type=pdf. But that does not give BFP title, and also places the cost of insurance premiums on the BFP, not the grantor.

173. Accord Sherrod v. Hollywood Holding Corp., 173 So. 33, 36 (Ala. 1937); Phelps v. Am. Mortgage Co., 104 P.2d 880, 884-85 (Cal. Ct. App. 1940); Blakeney v. Home Owners' Loan Corp., 135 P.2d 339, 340 (Okla. 1943); see, e.g., 28 AM. JUR. 2D Escrow $\$ 36$; 3 AMERICAN LAW OF PROPERTY $\$ 12.68$ (A. James Casner ed., 1952); $30 \mathrm{~A}$ C.J.S. Escrows $\$ 13$; 11 THOMPSON ON REAL PROPERTY, supra note 171, § 94.06(g) (4). A few jurisdictions might provide relief. See 28 AM. JUR. 2D Escrow $\$ 37$.

174. On the intent requirement in general, see 11 THOMPSON ON REAL PROPERTY, supra note $171, \S 94.06(\mathrm{~g})(1)$.

175. This differentiates a wrongful escrow delivery from the situation where a third party simply forges a grantor's name on a deed, where the general rule (correctly) holds that no title passes to a grantee or BFP. MILTON R. Friedman, FRIEDMAN ON CONTRACTS AND CONVEYANCES OF REAL PROPERTY $\$ 8.9$ (James Charles Smith ed., 7 th ed. 2006) [hereinafter FriEdMAN, FrIEDMAN ON CONTRACTS AND CONVEYANCES]. In a forgery case, the grantor has no role in chain of events. See id. ("A true owner may validate a forgery by his own carelessness, but an owner who entrusts a deed to an agent who commits the forgery does not transmit good title to the recipient of the forged deed."); Bellaire v. Kirkpatrick Joint Venture v. Loots, 826 S.W.2d 205, 211-12 (Tex. App. 1992) (evaluating grantor's liability for a deed entrustee's fraud under negligence principles). 
grantor is the "lowest cost avoider," and so the grantor should bear the burden. ${ }^{176}$

The general rule, favoring initial owners over successors, creates insecurity for future market transactions and will frustrate the legitimate expectations and aspirations of good faith successor buyers. This imbalance should be reversed. ${ }^{17}$

\section{Recording rules}

The recording acts and related rules were developed to establish a public system of land records that would protect ownership interests in land and accurately reflect that information for anyone to examine. This system has served to create an active and safe American real estate market by providing security of titles and realty interests, enabling the efficient use of land as collateral for loans, and allowing prospective buyers to locate owners and bargain with them over potential deals. ${ }^{178}$ While the recording acts differ among the states in some respects, they share many common models, attributes, and goals.

There are many aspects to the recording acts and related judicial decisions. This subsection will briefly explore two-misindexing and inquiry notice-that are examples of doctrines that unfortunately favor current ownership over successor holders. As a general proposition, the rules should not unfairly favor current owners over successor buyers and should not place excessive or irrational search burdens on potential future buyers. Otherwise, this will chill future market transactions and disappoint legitimate expectations. Courts should address these issues to protect future generation players.

\section{a. Misindexing}

The courts have had to decide whether a deed properly delivered for recording but subsequently misindexed by the recorder's office gives record notice to subsequent purchasers. The majority of

176. On the issue of lowest cost avoider in general, see Guido Calabresi \& Jon $\mathrm{T}$. Hirschoff, Toward a Test for Strict Liability in Torts, 81 YALE L.J. 1055, 1060 (1972); Guido Calabresi \& A. Douglas Melamed, Property Rules, Liability Rules, and Inalienability: One View of the Cathedral, 85 HARV. L. REV. 1089, 1118-19 (1972).

177. The grantor may soon discover the escrow agent's wrongdoing (e.g., failure to collect purchase price) and come forward before BFP conveys the property to other purchasers without notice. It may, thus, be unlikely that this problem extends temporally past proximate successors. But in at least some cases, the property might be re-sold to yet another BFP. See, e.g., Mosley v. Magnolia Petroleum Co., 114 P.2d $740,745-46$ (N.M. 1941) (property re-granted to three successive innocent buyers after original $B F P$ received the deed).

178. KoRNGOLD \& GOLDSTEIN, supra note 102, at 244-45. 
American jurisdictions hold that a subsequent purchaser is bound by a misindexed deed. ${ }^{174}$ This means that if O's deed to A is misindexed, $\mathrm{B}$, a subsequent BFP from $\mathrm{O}$, and any future BFP that takes from $\mathrm{B}$ or B's grantees, will lose title to $A .^{180}$ Future generations as well as proximate successors are at risk.

The majority rule is wrong in light of successor concerns. There is no way that a subsequent buyer could discover a misindexed deed by using standard operating procedures and thus there is no means to prevent the loss (i.e., paying good money for bad title). This can only have a negative effect on future market transactions. If the burden were placed instead on A to recheck that the instrument was properly indexed, it would add only a small cost to $\mathrm{A}$ and the system, as compared to the huge potential financial losses in a misindexing situation. This is especially important since it is unlikely that the disappointed subsequent purchaser can recover from the recorder for misindexing. ${ }^{181}$

\section{b. Inquiry notice}

Under the doctrine of inquiry notice, a buyer must make a reasonable inspection of the property before acquiring an interest and make a reasonable inquiry about other possible ownership claims that the inspection reveals. ${ }^{182}$ Moreover, the law imputes to the buyer the knowledge of other interests that such an inspection and inquiry would uncover. Failure to inspect, therefore, is at the buyer's own peril. $^{183}$ For example, a buyer considering purchasing Blackacre would inspect it and see $\mathrm{X}$ living there, make inquiry of $\mathrm{X}$, and find out that $\mathrm{X}$ had been given a deed to the property the day before by

179. Friedman, Friedman on Contracts and Conveyances, supra note $175, \$ 9.5$. See Luthi v. Evans, 576 P.2d 1064, 1070 (Kan, 1978); Haner v. Bruce, 499 A.2d 792 , 794 ( $V t .1985$ ) (real estate attachment valid though misindexed); see also First Citizens Nat'l Bank v. Sherwood, 879 A.2d 178, 182 (Pa. 2005). For jurisdictions following the minority rule, see Greenpoint Mortgage Funding, Inc. v. Schlossberg, 888 A.2d 297, 304 (Md. 2005); Howard Sav. Bank v. Brunson, 582 A.2d 1305, 1308-10 (N.J. Super. Ct. Ch. Div. 1990).

180. Standard title insurance policies would compensate B for the loss if B had purchased such a policy. See AM. LAND TITLE Ass'N, supra note 172, § (1) ("Title being vested other than as stated in Schedule A."). But that does not give B title and also places the cost of insurance premiums on $B$.

181. See, e.g., Siefkes v. Watertown Title Co., 437 N.W.2d 190, 193 (S.D. 1989).

182. CASNER ET AL., supra note 100 , at 749.

183. Title insurance would not protect a buyer who had purchased a policy because Schedule B typically excepts the company from liability due to rights of parties in possession whose interests are not recorded. See, e.g., Cheverly Terrace P'ship v. Ticor Title Inc., 642 A.2d 285, 290 (Md. Ct. Spec. App. 1994); Horn v. Lawyers Title Ins. Corp., 557 P.2d 206, 208-09 (N.M. 1976); Halvorson v. Nat'l Title \& Abstract Co., 391 S.W.2d 112, 114 (Tex. Civ. App. 1965). 
the owner, thus giving $X$ a superior interest to the new buyer. If the buyer failed to make such an inspection and inquiry, the buyer will still lose to $\mathrm{X} .{ }^{184}$

The problem is that many courts have taken an expansive view of the level of inspection and inquiry required by subsequent purchasers, exposing such purchasers to significant expense and risk of loss of their investment if they fail to meet this rigorous standard. In the leading case of Sanborm $v$. McLean ${ }^{185}$ the issue was whether the lot being sold was bound by a building restriction even though nothing appeared in the chain of title for the lot. ${ }^{186}$ The court declared a new doctrine and found that the lot was bound by an implied "reciprocal negative easement" based on restrictions in the deeds of other lots. ${ }^{187}$ Moreover, the court-in a huge stretch-held that the buyers had inquiry notice of this restriction. ${ }^{188}$ First, the court expanded the scope of the inspection. The court, in essence, required the buyers to inspect not only the property being sold but all of the properties in the neighborhood, and so recognize that all had houses on them. The court then required the buyers to make far-reaching inquiry and huge logical leaps and assumptions. Thus, the buyers had to draw a legal conclusion that the fact that all other properties had houses on them must be because they were subject to a restriction, rather than market forces, and so a restriction must have been implied against the buyers' lot-even though this was a new legal doctrine! The court, moreover, seemed to think that the buyers should have divined this implied restriction by asking their neighbors if they had written restrictions, even though only fifty-three of the ninety-one lots in the area had restrictions and the buyers could have ended up asking ten neighbors who did not have a restriction set out in their deeds. Sanborn represents a huge reach by the court to find inquiry notice, perhaps motivated by the desire to uphold subdivision arrangements. ${ }^{189}$ But the attitude of the court presents a frightening prospect to subsequent generation buyers who

184. See Vitale v. Pinto, 500 N.Y.S.2d 283, 285 (N.Y. App. Div. 1986); U.P.C., Inc. v. R.O.A. Gen., Inc., 990 P.2d 945, 954 (Utah Ct. App. 1999).

185. 206 N.W. 496 (Mich. 1925).

186. Id. at 497-98.

187. Id. at $496-98$.

188. Id. at 497.

189. For other decisions with a broad view of inquiry notice, see Van Sandt v. Royster, 83 P.2d 698, 702 (Kan. 1938) (purchaser found to have inquiry notice that servient property had sewer line easement running that benefited neighboring lot because servient property had modern plumbing requiring a drain); Lake Meredith Dev. Co. v. City of Fritch, 564 S.W.2d 427, 431 (Tex. Civ. App. 1978) (manhole covers gave inquiry notice of easement for underground sewer line). 
could well end up losing all or part of their property rights via excessive inquiry notice rules.

The inquiry notice doctrine stems from a noble policy and ethical viewpoint: the protection of known, prior interest holders in property. A strong inquiry notice doctrine may have been sensible in the early days of our nation when it was not as easy to travel to the county seat to record documents and preserve rights acquired in property. But today, it is quite simple and inexpensive for such interest holders to protect their property rights by recording. Doing so would save the subsequent buyer from the not insignificant expense of making an inspection and inquiry and would also avoid the potential loss of the investment. Importantly, inquiry notice does not involve the situation where the subsequent purchaser actually knows of A's prior interest. That subsequent purchaser would, and should, lose in such a case to A. Inquiry notice, rather, goes further and places an affirmative burden to inspect and inquire on the purchaser. Therefore, to protect the integrity of land markets and the legitimate expectations of successor buyers, the legislatures and courts should limit the burden and narrowly structure and apply the inquiry notice doctrine. ${ }^{190}$ In doing so, decision-makers would be providing a level playing field for future generations owning property.

\section{Scenario 3: Things Change}

Sometimes the geographical surroundings or essential facts related to a land allocation agreement change significantly over the course of this perpetual or long term arrangement. As a result, the deal as originally envisioned by the parties becomes fundamentally askew. This may have a profound effect on future generation owners of the property and there is a need for the law to respond effectively. This Section will briefly examine two such situations.

190. Indeed, I hope in a future Article to make the argument that the courts should abolish the inquiry notice doctrine as it applies 'o the physical inspection of the property situation described here. There may be a place for inquiry notice based on questions raised by recorded documents, since that may not greatly expand the buyer's burden. See, e.g., Mun. Trust \& Sav. Bank v. United States, 114 F.3d 99, 10103 (7th Cir. 1997); Winkworth Fuel \& Supply Co. v. Bloomsbury Corp., 253 N.W. 304, 309-11 (Mich. 1934). Alternatively, highly efficient, non-intrusive utility easements might be binding against subsequent purchasers without resorting to the fiction of inquiry notice. RESTATEMENT (THIRD) OF PROP. \$ 7.14(2) (2000). 


\section{Relocation of easements}

Over time, the original or successor owner of a property burdened by an easement may wish to relocate the easement (such as a roadway, utility line, drainage ditch, or other type of easement). Typically, the reason for this is that the present location interferes with uses that the burdened owner wishes to make of the property. Taking a strict contract approach, courts have traditionally refused to allow unilateral relocation of the easement and have required both parties to agree to a change. ${ }^{191}$

The traditional rule is wrong. It binds future owners of the land to a perpetual deal struck in the past that does not account for new realities on the ground. Moreover, strict adherence to the original arrangement frustrates optimal utilization of land resources. The burdened property owner cannot fully use the property, thus depriving the owner and the marketplace of a desirable resource. As long as the burdened owner assumes the cost of relocation and the new location fulfills the easement's purpose at least as well as the original, it is wasteful if not perverse for relocation to be barred. The policies inherent in the free alienability rule require flexibility and the trumping of strict contract notions in order to serve the market and personal aspirations of future generations of owners.

The Third Restatement of Property (Servitudes) has adopted an innovative position that allows the burdened property owner to relocate the easement. ${ }^{192}$ Some courts have followed this new articulation, supporting it with reasoning inherent in free alienability theory. These courts have stated that the relocation is "consonant with the beneficial use and development" of the burdened property; ${ }^{193}$ the new rule "strikes an appropriate balance between the interests of the respective estate owners by permitting the servient owner to develop his land without unreasonably interfering with the easement holder's rights;" 194 and "each property owner ought to be able to make the fullest use of his or her property allowed by law,

191. Korngold, Private Land USE ARrangements, supra note 104, $\$ 4.13$ (b); see Note, The Right of Owners of Servient Estates to Relocate Easements Unilaterally, 109 HARV. L. REV. 1693, 1709 (1996) ("[T] he majority rule . . requires that the owners of the dominant and servient estates agree prior to relocating an easement.").

192. RESTATEMENT (THIRD) OF PROP. $\$ 4.8(3)$ (2000).

193. Lewis v. Young, 705 N.E.2d 649, 653 (N.Y. 1998); see Susan F. French, Relocating Easements: Restatement (Third), Servitudes \$ 4.8(3), 38 Rfal Prop. Prob. \& Tr. J. 1, 10-14 (2003) (comparing the Third Restatement with traditional approaches and favoring Third Restatement approach).

194. M.P.M. Builders, L.L.C. v. Dwyer, 809 N.E.2d 1053, 1057 (Mass. 2004). 
subject only to the requirement that he or she not damage other vested rights holders." 195

The pliable Third Restatement rule has the disadvantage of increasing the likelihood of litigation and related costs when sorting out relocation questions. ${ }^{196}$ The traditional rule, establishing a clear veto right over relocation, forces the parties to bargain over the issue initially and avoids later litigation and its expense. Because the easement's duration is perpetual and the use of the land, occupants, and technology will inevitably change, however, it will be virtually impossible, and certainly very expensive, for the parties to gather the necessary information up front to adequately negotiate every future relocation issue. Thus, the flexible Third Restatement standard with its litigation expenses may in fact be no more expensive than a clear "no relocation" rule with its negotiation expenses and imperfections. Moreover, the Third Restatement rule will likely lead to more efficient land allocation.

Unfortunately, the enlightened Third Restatement view has been rejected by other modern courts. ${ }^{197}$ These court toss out some big buzzwords to justify their position-"uniformity, stability, predictability, and property rights" ${ }^{\text {"198 }}$ and "fairness"199-but do not explain how these words are relevant to the issue. Moreover, one court's explanation of its decision indicates that it views the dispute as a simple, first-generation contract matter: "No doubt, when the servitude was first created both parties considered all market factors, including their respective costs and benefits, before agreeing on the consideration for the transaction." 200 This misses the generational, perpetuity, and free alienability issues.

\section{Changed conditions}

The law has developed the doctrine of changed conditions to release parties from a covenant obligation in certain altered factual situations. A typical case arises when physical conditions and facts on the ground have developed so that a subdivision is no longer viable for residential purposes, and thus the enforcement of a residential building or use restriction against a violating owner is meaningless

195. Roaring Fork Club, L.P. v. St. Jude's Co., 36 P.3d 1229, 1237 (Colo. 2001 ).

196. See French, supra note 193 , at 15.

197. See, e.g., Sweezey v. Neel, 904 A.2d 1050, 1058 (Vt. 2006); see also John Orth, Relocating Easements: A Response to Professor French, 38 REAL PROP. PROB. \& TR. J. 643, 653-54 (2004) (opposing the Third Restatement's position).

198. MacMeekin v. Low Income Hous. Inst., 45 P.3d 570, 579 (Wash. Ct. App. 2002).

199. Herren v. Pettengill, 538 S.E.2d 735, 736 (Ga. 2000).

200. Id. 
and oppressive. ${ }^{201}$ The changed conditions argument may be based on past failures to enforce the restriction against other owners with ensuing construction and uses violating the covenant. ${ }^{202}$ Acts of third parties may also make the residential subdivision scheme no longer viable, such as a governmental taking of a large, central portion of the development ${ }^{203}$ or technological changes. ${ }^{204}$

The changed conditions doctrine, if fully conceptualized and applied, represents a positive example of decision-makers giving due consideration to future generations in enforcing perpetual land allocation agreements. Often the courts attempt to justify the doctrine as achieving the parties' initial intent, ${ }^{205}$ thus rooting it firmly in the concept of freedom of contract. They maintain that, because of the changed circumstances, the parties' initial contract goals cannot be achieved. The parties, therefore, would not have desired for the covenant to be enforced. The changed conditions rule might be better understood, however, as a function of the free alienability doctrine. Through application of the changed conditions doctrine as an extrinsic rule of law, the courts are able to sweep away obsolete, perpetual land ties and allow current owners to utilize the property in societally and personally beneficial market transactions. ${ }^{206}$ Thus, the doctrine represents an appropriate triumph of free alienability over contract. ${ }^{207}$

To fully effectuate free alienability goals, however, the changed conditions doctrine must be applied correctly by courts. Some have seen the doctrine as only equitable in nature and as only providing

201. RESTATEMENT (THIRD) OF PROP. $\$ 7.10$ (2000).

202. See, e.g., El Di, Inc. v. Town of Bethany Beach, 477 A.2d 1066, 1068-70 (Del. 1984); Plumb v. Ruffin, 328 N.W.2d 792, 793-94 (Neb. 1983); Medearis v. Trs. of Meyers Park Baptist Church, 558 S.E.2d 199, 206-08 (N.C. Ct. App. 2001); Young v. Cerone, 487 A.2d 965, 969-70 (Pa. Super. Ct. 1985).

203. Burnett v. Heckelman, 456 N.E.2d 1094, 1096 (Ind. Ct. App. 1983). For cases where a zoning change brought about or at least signaled changed conditions, see Owens v. Camfield, 614 S.W.2d 698, 700 (Ark. Ct. App. 1981); Marks v. Wingfield, 331 S.E.2d 463, 465 (Va. 1985).

204. Zavislak v. Shipman, 362 P.2d 1053, 1055-56 (Colo. 1961); Lenhoff v. Birch Bay Real Estate, Inc., 587 P.2d 1087, 1089-90 (Wash. Ct. App. 1978).

205. See, e.g., Downs v. Kroeger, 254 P. 1101, 1102-03 (Cal. 1927); Dierberg v. Wills, 700 S.W.2d 461, 467 (Mo. Ct. App. 1985); Roadrunner Dev. Inc. v. Sims, 330 N.W.2d 915, 918-21 (Neb. 1983).

206. See Susan F. French, Toward A Modern Law of Servitudes: Reweaving the Ancient Sirands, 55 S. CAL. L. REv. 1261, 1300-02 (1982); Michael Heller, The Boundaries of Private Property, 108 YALE L.J. 1163, 1163 (1999); Reichman, supra note 92, at 1258-59. For an analogous doctrine permitting deviation from the terms of a trust, see Colonial Trust Co. v. Brown, 135 A. 555, 564 (Conn. 1926).

207. Some, however, disagree with this interference with property rights. See, e.g., Ellickson, supra note 92, at 716-17; Carol M. Rose, Servitudes, Security, and Assent: Some Comments on Professors French and Reichman, 55 S. CAL. L. REv. 1403, 1409-16 (1982). 
relief from an injunctive action. ${ }^{208}$ The public policy of removing obsolete land ties and making land available for market transactions applies as well, though, in cases seeking damages. Thus, courts and legislatures should follow the lead of those trailblazing courts that have applied the changed conditions doctrine to fully extinguish a covenant. $^{209}$

\section{Scenario 4: Poor Predictions by Private Parties}

Some parties focus on the perpetual nature of land transactions, but others do not. Moreover, in certain situations, the parties are aware of the perpetual nature of their deal but mistakenly or misguidedly neglect to inject flexibility into their scheme and so fail to ensure that it will continue to serve the needs of successor owners. As developed above, generally the benefits of freedom of contract support the enforcement of the land contract as written; the need for flexibility inherent in free alienability, however, means that on very few occasions the strict contract approach must give way in order to protect future generations. Two common situations illustrate this interplay with future generations-residential communities governed by servitudes and conservation easements owned by nonprofit organizations.

\section{Residential communities}

The demand for suburban living in the face of an urbanizing America, the growing professionalism of the home building industry, and the development of mass production techniques led to the emergence of large-scale developers of sizable residential subdivisions in the early twentieth century. ${ }^{210}$ These subdivisions typically imposed a regime of building and use restrictions (often including architectural guidelines), installed infrastructure for the owners (such as roads and utilities), often provided communal amenities (such as recreational facilities and parks) for the residents, and sometimes created elected private governments of the homeowners

208. This position is embodied in the first Restatement of Property. Restatement of PROP. \$ 564 cmt. d (1944); accord Strong v. Shatto, 187 P. 159, 162-63 (Cal. Dist. Ct. App. 1919).

209. This position has been embraced by the Restatement (Third) of Property, as well as in some cases involving quiet title actions that completely void covenants under the theory. Restatement (ThIRD) OF PROP. $\$ 7.10(1)(2000)$; see, e.g., Hirsch v. Hancock, 343 P.2d 959, 969 (Cal. Dist. Ct. App. 1959); Osius v. Barton, 147 So. 862, $867-68$ (Fla. 1933).

210. MARSH, supra note 56, at 1-7; MARC WeISS, THE RISE OF THE COMMUNTTY BuILDers 45 (Columbia Univ. Press 1987); see Wayne S. Hyatt, Common Interest Communities: Evolution and Reinvention, 31 J. MARSHALL L. REV. 303, 319 (1998). 
to enforce and steward the servitude scheme. ${ }^{211}$ The legal vehicle to accomplish this was a scheme of covenants (real covenants and equitable servitudes) and easements. These subdivisions were seen as serving important, then emerging and still valued social policiesprotection of the family home, fostering a positive communal setting for families and children, efficiently offering recreation facilities at a shared cost, and use of democratic principles of self-governance. ${ }^{212}$

Early on in the subdivision process, the developers and their legal counsel were not as sophisticated as they would eventually become in conceptualizing and structuring the legal arrangements. Many simply did not pay attention to the perpetuity issue-the fact that under traditional doctrines, easements and covenants would last forever unless they were specifically limited, which many failed to do. ${ }^{213}$ The failure to provide flexibility, however, is not limited to the drafters. Over the passage of time, issues related to perpetuity have worked their way through the courts. Many courts do not understand the need to inject flexibility into these perpetual arrangements in order to make them effective and even viable. They instead slavishly follow contract values and rigidly adhere to the written document. Some courts do get it right, though, and go beyond a strict construction approach. They apply a flexible solution that the current owners must have intended when they purchased the property and that is necessary for the viability and health of the subdivision scheme. ${ }^{214}$ Consider these examples, the first set dealing with the operation of the community and the second with the subject matter of the covenants.

In terms of operation of the community, some of the original subdivision covenants provided for fixed amounts of annual dues for maintenance of common areas. These amounts proved insufficient over time with inflationary pressures and the need to do restorative work. Most courts, however, permit dues increases only if the covenant specifically so provided and the courts will not generally

211. Korngold, Owners Associations, supra note 57. For an examination of one of these developments, see Gerald Korngold, The Emergence of Private Land Use Controls in Large-Scale Subdizisions: The Companion Story to Village of Euclid v. Ambler Realty Co., 51 CASE W. RES. L. REV. 617, 625 (2001) [hereinafter Korngold, Village of Euclid].

212. See generally Beverly Island Ass'n v. Zinger, 317 N.W.2d 611, 613 (Mich. Ct. App. 1982); Swaggerty v. Petersen, 572 P.2d 1309, 1313 (Or. 1977).

213. See, e.g., Moseley v. Bishop, 470 N.E.2d 773, 773 (Ind. Ct. App. 1984); Hillis v. Powers, 875 S.W.2d 273, 273 (Tenn. Ct. App. 1994); Thayer v. Thompson, 677 P.2d 787, 787 (Wash. Ct. App. 1984); see also Restatement (THIRD) OF PROP. $\$ 4.3$ (2000).

214. This is a different matter than the use of extrinsic evidence to determine and apply the intent of the original parties in Scenarios 1 and 2. It is certainly appropriate for the courts to consider what the current owners intended when they made their deals. 
impose an increase without such clear authorization. ${ }^{215}$ Contrary holdings are rare, albeit praiseworthy. ${ }^{216}$ Similarly, where there is no provision at all to pay dues in the original documents, courts have usually refused to imply such a covenant even though there are common areas requiring maintenance included in the original scheme. ${ }^{217}$

Covenants have at times perpetrated a major assault on human dignity and value. In the past, subdivision covenants were shamefully employed to bar racial minorities (notably African Americans and Asian Americans) and religious minorities (notably Jews) from owning homes within the community. ${ }^{218}$ The law of property was unfortunately not up to the task of voiding these covenants as violating public policy, and it was left to the United States Supreme Court to broadly read "state action" to find that they violated the Fourteenth Amendment. ${ }^{219}$

Problems with the subject matter of covenants can be exacerbated with the change of communal norms over time. One variety of covenants limits ownership and occupancy within a subdivision to "traditional" single families, defined in the document. ${ }^{220}$ These

215. See, e.g., Loganecker v. Diamondhead Country Club, 760 So. 2d 764, 771 (Miss. 2000); Sanderson v. Hidden Valley Fishing Club, 743 S.W.2d 486, 487 (Mo. Ct. App. 1987); Beech Mountain Prop. Owners' Ass'n v. Seifar, 269 S.E.2d 178, 183 (N.C. Ct. App. 1980); Birchwood Lakes Cmty. Ass'n v. Comis, 442 A.2d 304, 307 (Pa. Super. Ct. 1982).

216. See, e.g., Covlin v. Carr, 799 S.W.2d 153, $157-58$ (Mo. Ct. App. 1990) (allowing an increase of dues above the original fifty cents per foot of frontage to cover security patrols necessitated by high crime in the area and to prevent dissenting owners from getting a free ride; basing its decision on the overall intent of the regime to create "a desirable residential section"). There is no contradiction between advocating for a flexible interpretation of the dues covenant in these cases and calling for a plain meaning construction in general deed interpretation in Section IV.A, supra. In both situations, the focus is on the legitimate expectation of the current owner at the time that owner purchased the property. In the earlier discussion that expectation could only extend to what that owner could reasonably take the recorded document to mean; in the subdivision context, the owner would understand that he or she is purchasing a property in a functioning, community living arrangement and can legitimately expect the benefits and burdens that come with that.

217. See, e.g., Lakeland Prop. Owners Ass'n v. Larson, 459 N.E.2d 1164, 1168 (Ill. App. Ct. 1984); Amana Soc'y v. Colony Inn, Inc., 315 N.W.2d 101, 115 (Iowa 1982); Woodland Beach Prop. Ass'n v. Worley, 252 A.2d 827, 831 (Md. 1969); Mercury Inv. Co. v. F.W. Woolworth Co., 706 P.2d 523, 529-30 (Okla. 1985). Some other courts, fortunately, reject this view. See, e.g., Island Improvement Ass'n v. Ford, 383 A.2d 133, 133 (N.J. Super. Ct. App. Div. 1978); Sea Gate Ass'n v. Fleischer, 211 N.Y.S.2d 767, 767 (N.Y. 1960); Meadow Run \& Mountain Lake Park Ass'n v. Berkel, 598 A.2d 1024, 1026 (Pa. Super. 1991); RESTATEMENT (ThIRD) OF PROP. $\$ 6.5$ (2000).

218. Korngold, Village of Euclid, supra note 211, notes 107-24 and accompanying text.

219. Shelley v. Kraemer, 334 U.S. 1, 19, 23 (1948). Such restrictions, though unenforceable, still remain of record. Motoko Rich, Restrictive Covenants Stubbormly Stay on the Books, N.Y. TimeS, Apr. 21, 2005, at D1.

220. Korngold, Single Family, supra note 50, at 979-83. 
covenants do not account for the monumental changes in living arrangements within American homes, now common in the twentyfirst century. Because the intrusion on personal autonomy of residents is so great, free alienability principles should trump freedom of contract notions, and courts should deny strict enforcement of these agreements. For doctrinal support to strike these covenants, courts can rely on the touch and concern rule, ${ }^{221}$ a prohibition of enforcement of covenants violating public policy, ${ }^{222}$ or a rule that enforces only covenants that prevent harmful spillovers on the rest of the community and do not limit choices within the privacy of the family home. ${ }^{223}$ Subject matter has continued to present contract/autonomy conflicts, such as with subdivision prohibitions on flying flags. Courts have usually addressed these as a Constitutional issue, with some reaching to find state action by the association and so striking the bans. ${ }^{224}$ Ultimately the United States Congress preempted the issue with the Freedom to Display the American Flag Act of $2005 .^{225}$

Therefore, the subdivision experience has demonstrated that, as a general matter, subdivision covenants should be enforced as written because of their efficiency and freedom of choice benefits. Their perpetual nature, however, may require rare deviations under free alienability theory from the constraints that they impose on personal behavior and expression. A regime of potentially perpetual property rights is most effective and valuable when there are built-in safety valves. For example, drafters have learned to provide for limited duration of subdivision schemes through termination after a fixed term unless a set percentage of owners agrees to renew ${ }^{226}$ or for an automatic renewal after the initial term unless a set percentage

221. The touch and concern rule was an inartful device to police subject matter and has been rejected by the new Restatement. RESTATEMENT (THIRD) OF PROP. $\$ 3.2$ (2000); A. Dan Tarlock, Touch and Concern is Dead, Long Live the Doctrine, 77 NeB. L. REv. 804, 804 (1998).

222. Korngold, Private Land Use Arrangements, supra note 104, § 10.02.

223. Architectural controls should be permitted, as long as they are applied reasonably, since design of a home can have a severe impact on the value and aesthetic of neighboring properties.

224. See, e.g., Gerber v. Longboat Harbor N. Condo., Inc., 724 F. Supp. 884, 886 (M.D. Fla. 1989), vacated in part, 757 F. Supp. 1339 (M.D. Fla. 1991); see also Comm. for a Better Twin Rivers v. Twin Rivers Homeowners' Ass'n, 890 A.2d 947, 962-63 (N.J. Super. 2006) (concerning political signs and other issues), cert. denied, 897 A.2d 1061 (2006); Joe Kollin, Condo Rule Against Mezuza is Discriminatory, Resident Says, S. Fla. Sun-SEnTINEL, Feb. 3, 2007, at B6.

225. Freedom to Display the American Flag Act of 2005, Pub. L. No. 109-243, 120 Stat. 572 (2005).

226. See, e.g., Sampson v. Kaufman, 75 N.W.2d 64, 66 (Mich. 1956); Lake Wauwanoka, Inc. v. Spain, 622 S.W. 2d 309, 310 (Mo. Ct. App. 1981). 
terminates. ${ }^{227}$ On other issues where drafters have failed to provide needed flexibility, courts and legislatures should respond with creative solutions. ${ }^{228}$

\section{Conservation easements}

The touchstone of conservation easements has not been flexibility but rather strict adherence to the status quo. These perpetual property interests are designed to forever preserve the current natural or ecological state of the burdened property. Conservation easements serve the important societal goal of conservation, especially in the face of ongoing development. However, the perpetual nature of these interests-reflecting a choice made by the original parties-may, in some situations, create intractable problems. Freedom of contract principles are dominant in the conservation easement movement, sometimes at the expense of fundamental free alienability values.

A conservation easement is a negative restriction that prevents the owner of the burdened land from altering the natural, open, scenic, or ecological features of the land. ${ }^{229}$ Governmental entities have held conservation easements in the past. ${ }^{230}$ Over the past thirty years, private non-profit organizations have been permitted to own them, ${ }^{231}$ most usually through the passage of the Uniform Conservation Easement Act. The Act helped overcome the traditional hurdle to the holding of in gross interests. ${ }^{232}$ It also used the term "easement" even though the conservation interests most closely resemble a

227. See, e.g., Shalimar Ass'n v. D.O.C. Enters., Ltd., 688 P.2d 682, 684 (Ariz. Ct. App. 1984); Bob Layne Contractor, Inc. v. Buennagel, 301 N.E.2d 671, 674 (Ind. Ct. App. 1973).

228. See Restatement (ThIRD) OF Prop. $\$ 7.1$ (2000) (providing for extensive modification of covenants to get flexibility.); Uniform Common Ownership Interest Area Act $\$ 2-117,7$ U.L.A. 72, 73 (2002) (allowing an amendment when at least sixtyseven percent of the votes in the association are allocated); $i d$. $\$ 2-118$ (a) (permitting termination by vote when at least eighty percent of total votes agree).

229. See Uniform Conservation Easement Act $\$ 1,12$ U.L.A. 170 (1996); Restatement (ThIRd) OF Prop. \$ 1.6 (2000); Gerald Korngold, Privately Held Conservation Servitudes: A Policy Analysis in the Context of In Gross Real Covenants and Easements, 63 TEx. L. REv. 433, 433 (1984) [hereinafter Korngold, Conservation Servitudes]; see also Roger Cunningham, Scenic Easements in the Highway Beautification Program, 45 DENV. L. J. 167, 167 (1968); Ross D. Netherton, Environmental Conservation and Historic Preservation Through Recorded Land-Use Agreements, 14 REAL PROP. PROB. \& TR.J. 540, 540 (1979).

230. See, e.g., Coons v. Carstensen, 446 N.E.2d 114, 115 (Mass. App. Ct. 1983); Kamrowski v. State, 142 N.W.2d 793, 795-96 (Wis. 1966).

231. See, e.g., United States v. Blackman, 613 S.E.2d 442, 447-49 (Va. 2005).

232. Uniform Conservation Easement Act $\$ 4(1)$. For cases barring in gross enforcement of covenants under traditional rules, see Marra v. Aetna Constr., 101 P.2d 490, 493 (Cal. 1940); Orenberg v. Horan, 168 N.E. 794, 796 (Mass. 1929); Minch v. Saymon, 233 A.2d 385, 388-89 (N.J. Ch. 1967). 
negative (restrictive) covenant. Conservation easements are perpetual, as provided for in the Act. ${ }^{233}$ This reflects the firm belief by conservation proponents that the land must be permanently preserved in order to achieve conservation goals. ${ }^{234}$ Moreover, the Internal Revenue Code, which provides a public subsidy for the donation of conservation and historic preservation easements to charitable organizations, requires that the interest be perpetual in order to qualify. ${ }^{235}$

Conservation easements reflect an important new attitude towards American land. Rather than seeing property only as an asset to be developed and exploited, over the past four decades we have witnessed a burgeoning environmental consciousness in this country and a desire to preserve our natural and historical heritage. ${ }^{236}$ Conservation easements are especially attractive since they do not require the high acquisition expenses of fees, private rather than governmental funds are expended initially and in ongoing supervision, and government's role is limited in favor of private action. ${ }^{237}$

Despite the great benefits of conservation easements, their perpetual nature and lack of flexibility may present several major problems for future generations. First, notions of what should be conserved and methods of preservation may evolve over time, so that immutable conservation easements may not fulfill their stated goals in the future. ${ }^{238}$ Moreover, there may come a point in the future when the public interest for economic development of a parcel may outweigh the conservation goal. ${ }^{239}$ Because the interest is held by a (perhaps geographically distant) private organization rather than the

233. Uniform Conservation Easement Act $\S 2(c)$.

234. See United States v. Little Lake Misere Land Co., 412 U.S. 580, 597 (1972); Russell Brenneman, PrIVATE APProaches to the Preservation OF OPEN LAND 20 (1967); Netherton, supra note 229, at 542.

235. I.R.C. $\S 170(\mathrm{~h})(4)$ (A) (iii) (1999). In 2003 , there was a total of $\$ 1.49$ billion deducted under the I.R.C. for contributions of conservation and historic easements. JANETTE WILSON \& MichaEL STRUDLER, INDIVIDUAL NONCASH Charitable CONTRIBUTIONS, 60 (2003), http://www.irs.gov/pub/irs-soi/03inccart.pdf.

236. See Richard Brewer, Conservancy: The Land Trust Movement in America 57-77 (Univ. Press of New England 2003); RODERICK FRAZIER NASH, WILDERNESS AND THE AMERICAN MIND 238-71 (3d ed. 1983).

237. Korngold, Conservation Servitudes, supra note 229, at 443-47. Note, however, the public subsidy through the I.R.C. deduction.

238. Julia D. Mahoney, Perpetual Restrictions on Land and the Problem of the Future, 88 VA. L. REV. 739, 762 (2002).

239. American Museum of Natural History, Theodore Roosevelt Quotes, http://www.amnh.org/common/faq/quotes.html (last visited June 24, 2007) ("The nation behaves well if it treats the natural resources as assets which it must turn over to the next generation increased; and not impaired in value. Conservation means development as much as it does protection."). 
local government, this key matter of local land use will not be the subject of public policy debate based on the democratic process but rather left to a private group with a predetermined agenda. ${ }^{240}$ This absentee veto power is potentially harmful. It might also raise class issues where a conservation organization favors preservation over economic development needed by working families or where conservation easements are used as private "large-lot zoning" to bar affordable housing. ${ }^{241}$

There may be stewardship problems as well if the conservation organization lacks the resources to monitor and enforce the easement. This would deny the public the benefit of a desirable and publicly subsidized conservation restriction. ${ }^{242}$ Similarly, since conservation easements are in effect covenants in gross (i.e., the nonprofit does not have to own a neighboring property benefited by the restriction), ${ }^{243}$ it may be difficult to locate the owner of the interest. This would make it difficult or impossible to negotiate the release or amendment of the conservation easement. ${ }^{244}$

In the face of these significant challenges raised by perpetuity, the public is left to common law doctrines designed for other situations to attempt to re-shape the perpetual conservation easement. ${ }^{245}$ Combined with the statutory framework of the Uniform Act and the Internal Revenue Code incentive for perpetuity, flexibility cannot easily be accommodated in current conservation easement law.

240. As detailed in Scenario 5, eminent domain may no longer be an option to wipe out the conservation easement if the underlying purpose is economic development.

241. Korngold, Conservation Servitudes, supra note 229, at 457-63. Consider, for example, the recent dispute between environmentalists seeking to preserve scenery and immigrant laborers crowded into housing in Monterey, California. Miriam Jordan, In Tony Monterey County, Slums and a Land War, WALL ST. J., Aug. 26, 2006, at A1; see Jim Staats, Crowd Rips Habitat for Humanity Proposal, MARIN INDEP. J., Jan. 17, 2007, www.marinij.com/marin/ci_5029025 (chronicling four affordable housing units criticized for causing an alleged increase in traffic and being out of character with neighborhood); Brad Wolverton, Conservation Charities Come Under Questioning by the Senate, Chron. OF Philanthropy, June 23, 2005, at 4.

242. Carol Necole Brown, A Time to Preserve: A Call for Formal Private-Party Rights in Perpetual Conservation Easements, 40 GA. L. REv. 85, 142 (2005); Jessica E. Jay, Land Trust Risk Management of Legal Defense and Enforcement of Conservation Easements: Potential Solutions, 6 ENvTL. LAw. 441, 496 (2000); Lisa Black \& Courtney Flynn, Couple Sue Neighbor Over Use of Conservation Land, CHI. TRIB. (Metro North Shore Ed.), Dec. 1,2005 , at 1 .

243. Supra Section III.A.1.b.

244. For a discussion of the loss of property interests from the common pool, see Michael Heller, Tragedy of the Anticommons: Property in Transition from Marx to Markets, 111 HARV. L. REV. 621, 687 (1998).

245. Susan F. French, Perpetual Trusts, Conservation Servitudes, and the Problem of the Future, 27 CARDOzo L. REv. 2523, 2526 (2006); Nancy McLaughlin, Rethinking the Perpetual Nature of Conservation Easements, 29 HARV. ENVTL. L. REv. 421, 426-27 (2005). 
Future generations will have to suffer the ironclad choices that were made for them.

Perpetuity certainly has it attractions, both in the case of subdivision covenants and conservation easements. Freedom of contract and the language of the governing instrument should not lightly be ignored. Yet, as this Section has shown, there are rare occasions where flexibility is essential, and the contract value must yield to alienability concerns in order to protect future generations.

\section{E. Scenario 5: The End of the Eminent Domain Trump Card?}

Kelo $v$. City of New London ${ }^{246}$ was correctly decided. Despite the overwhelming criticism of the Court's decision, the result and doctrine announced in the case preserve for future generations an essential tool for them to remedy the missteps of the past and develop community-based, land use plans that will meet the currently unknowable, ultimately pressing needs of the future. ${ }^{247}$ The Court's permitted intrusion on property/contract rights strikes the appropriate balance.

In Kelo, the city of New London responded to decades of economic decline by entering into a collaborative arrangement with a nonprofit organization ("NLDC") to revitalize the city's business base. After public hearings, NLDC developed an integrated development plan for ninety waterfront acres in New London. The plan, involving 115 private properties and thirty-two acres of former Navy land, received city council and state approval. The planned development included new residences, a hotel, a park and marina, and major office and retail space. When NLDC initiated condemnation proceedings pursuant to the plan, several private homeowners (Petitioners) objected. The public was willing to pay for these properties; the issue was whether the land was being taken for a "public use" under the Fifth Amendment. ${ }^{248}$

The Kelo Court rejected two challenges to the "public use" requirement. First, it did not matter that Petitioners' land was not "blighted" in order to find a valid "public use." The Court instead deferred to the legislative determination (based on a thorough deliberation and a comprehensive plan) and the principle of federalism. The city's goal of "economic rejuvenation" and its belief that it was necessary and would be beneficial to the community was

246. 545 U.S. 469 (2005).

247. Id. at $489-90$.

248. Id. at 474. 